\title{
Influence of season-depending ecological variables on biomarker baseline levels in mussels (Mytilus trossulus) from two Baltic Sea subregions
}

\author{
Denis Benito ${ }^{\mathrm{a}}$, Aino Ahvo ${ }^{\mathrm{b}}$, Jari Nuutinen ${ }^{\mathrm{c}}$, Dennis Bilbao ${ }^{\mathrm{d}}$, Jon Saenz ${ }^{\mathrm{e}}$, Nestor Etxebarria ${ }^{\mathrm{d}}$, Xabier Lekube ${ }^{\mathrm{a}}$,

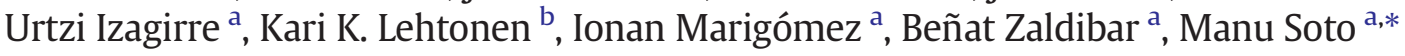

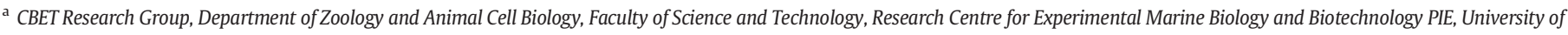 \\ the Basque Country UPV/EHU, Sarriena z/g, Leioa, Basque Country, Spain \\ b Finnish Environment Institute, Marine Research Centre, Agnes Sjöbergin katu 2, FI-00790 Helsinki, Finland \\ ${ }^{c}$ Finnish Environment Institute, Laboratory Centre, Ultramariinikuja 4, FI-00430 Helsinki, Finland \\ d IBEA Res Grp, Analytical Chemistry Dept. (Science and Technology Fac.), Univ Basque Country (UPV/EHU), PO Box 644, E-48080 Bilbao, Basque Country, Spain \\ e Department of Applied Physics II, University of the Basque Country (UPV/EHU), B. Sarriena s/n, Leioa 48940, Spain
}

\section{H I G H L I G H T S}

- Baltic Sea presents regional and seasonal changes that condition responses in mussels.

- Food supply dictated reproductive cycle and consequently biomarker response.

- Seasonal variability unequally reflected at different biological organization levels.

- Combination of biological and ecological data necessary for biomarker approach

\section{A R T I C L E I N F O}

\section{Article history:}

Received 24 April 2019

Received in revised form 24 June 2019

Accepted 24 June 2019

Available online 26 June 2019

Editor: Henner Hollert

\section{Keywords:}

Biomarkers

Biomonitoring

Baltic Sea

Reference values

\footnotetext{
* Corresponding author.

E-mail address: manu.soto@ehu.eus (M. Soto).
}

G R A P H I C A L A B S T R A C T

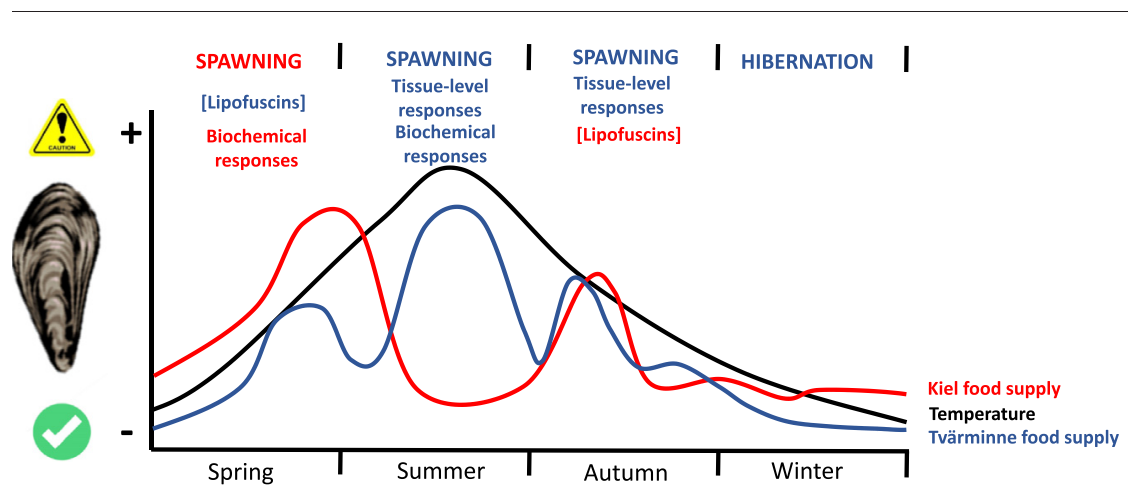

\begin{abstract}
A B S T R A C T
For reliable mussel monitoring programmes based on biomarkers, regionally relevant reference values and their natural variability need to be known. The Baltic Sea exhibits high inter-regional and seasonal variability in physical factors such as salinity, temperature and primary production. The aim of this pilot study is to depict the effects of season-related environmental factors in a selected battery of biomarkers in two environmentally different subregions of the Baltic Sea to help establishing reference data for biochemical, cellular and tissue-level biomarkers. In order to achieve that, mussels were collected from reference sites in Kiel (Germany) and Tvärminne (Finland) during three seasons: summer and autumn 2016, and spring 2017. Finally, in order to characterize the ecological situation, analysis of the chemical tissue burden was performed and chlorophyll $a$ and particulate organic carbon concentration and temperature changes were analyzed at each sampling locality using satellite remote sensing images. An integrated biomarker response index was performed to summarize the biomarker responses of each locality and season. The biochemical endpoints showed seasonal variability regulated by temperature, food supply and reproductive cycle, while among the cellular endpoints only lipofuscin accumulation and lysosomal structural changes showed slight seasonal variation. Seasonal changes in tissue level biomarkers were
\end{abstract}


observed only at the northern Baltic Sea site Tvärminne, dictated by the demanding energetic trade-off caused by reproduction. In conclusion, the characterization of the ecological variables and physico-chemical conditions at each site, is crucial to perform a reliable assessment of the effects of a hypothetical pollution scenario in the Baltic Sea. Moreover, reference levels of biomarkers and their responses to natural environmental conditions must be established.

(c) 2019 The Authors. Published by Elsevier B.V. This is an open access article under the CC BY-NC-ND license (http:// creativecommons.org/licenses/by-nc-nd/4.0/).

\section{Introduction}

Levels of pollutants have increased in the marine environment due to human activities. As a consequence, the impoverishment of the quality of water and sediments can involve alterations in marine organisms. Thus, to perform an assessment of the risk posed by pollutants associated to human activities is necessary. Environmental health assessments cannot be performed solely based on chemical analysis as it does not provide information on adverse effects exerted by contaminants on living organisms. Therefore, the measurement of pollutantinduced biological effects has become of major importance for these assessments (Cajaraville et al., 2000; Rementeria et al., 2016; Benito et al., 2017).

Mussels, especially those belonging to the genus Mytilus, are the most widely used sentinel organisms in pollution monitoring programmes with the objective of studying the health of coastal and estuarine ecosystems (Cajaraville et al., 2000; Marigómez and BaybayVillacorta, 2003; Nasci et al., 2002; Brenner et al., 2014). Mussels tolerate exposure to chemical stressors and respond in a broad range of ways, which can be measured by means of the biomarker approach (Garmendia et al., 2011).

During the recent decades, the application of biomarkers in aquatic organisms as indicators of the biological effects of pollution has been widely established. Biomarkers are valuable tools for environmental health assessment. However, to come up with a correct interpretation of the biological responses measured to discriminate the effect of a hypothetical chemical stressor it is necessary to recognize the ranges of natural variability under different ecological conditions such as temperature, salinity and food availability (Leiniö and Lehtonen, 2005; Nahrgang et al., 2013; Beyer et al., 2017; Storhaug et al., 2018).

The brackish-water Baltic Sea is characterised by extensive temporal and spatial variability in environmental factors. For example, temperature and salinity vary according to season (fluctuating from 0 to ca. 20 ${ }^{\circ} \mathrm{C}$ ) and latitude (salinity of ca. 18-20 in the southwest and 3-4 in the very northern parts). This substantial variability requires physiological adaptations in species, and effects of seasonal variations in biological responses measured as biomarkers can therefore be expected.

The two Baltic Sea study areas selected in the present work have been shown to exhibit low levels of pollutants in previous studies (e.g., Turja et al., 2015) and are characterised by different environmental conditions. Therefore, it is reasonable to expect that the effect of seasonality on the biota varies between the localities. The development and dynamics of the intensive spring bloom can be verified by the decrease in concentrations of dissolved inorganic nutrients and the increase in chlorophyll concentrations in the water. Water temperature varies usually between 0 and ca. $20^{\circ} \mathrm{C}$ during the year, and large parts of the Gulf of Finland is usually covered by ice from the end of January until early April, although the duration of the ice period varies each year depending on prevailing weather conditions. During the melting of ice, phytoplankton production increases rapidly and the spring bloom in the Gulf of Finland generally reaches a maximum in early May (Leiniö and Lehtonen, 2005). In the central and northern part of the gulf massive (toxic) cyanobacterial blooms occur every summer, normally in early/ mid July-early August (Lehtonen et al., 2003). The western Baltic Sea is strongly influenced by the periodic near-bottom inflow of marine North Sea water (mainly in winter) and more or less continuous outflow of brackish Baltic Sea water near the surface (increasing from
February through the summer). In this part, the main growth period of the phytoplankton bloom ranges from mid-February to mid-March or from mid-March to the beginning of April. These differences in timing are related to yearly meteorological and hydrographical variations. When there is an increase in vertical mixing (around September) resulting in upward transport of remineralised nutrients from the bottom water, an autumn bloom can occur (Wasmund et al., 2008).

Marine pollution monitoring programmes are increasingly including molecular, cell and tissue-level biomarkers, applied in combination, for the assessment of biological effects of pollutants (Marigómez et al., 2013). However, the responsiveness of biomarkers can be affected by intrinsic confounding factors such as the reproductive status of sentinel organisms. Thus, variability in some biomarker responses is a natural feature of the annual physiological cycle of the species (Sheehan and Power, 1999). More precisely, the remarkable seasonal variability in temperature and food abundance observed in the Baltic Sea (Kautsky, 1982) gives rise to a more marked annual pattern in their reproductive cycle of mussels than encountered in many other seas (Ortiz-Zarragoitia et al., 2011; Azpeitia et al., 2017). Therefore, the main goal of this pilot study was to depict the effects of season-related environmental factors on a selected battery of biomarkers in two environmentally different subregions of the Baltic Sea in order to establish reference data for biomonitoring purposes. For this, mussels were collected from the western Gulf of Finland and the western Baltic Sea in different seasons to study the natural variability using a battery of biomarkers representing responses at different levels of biological complexity. To start with the characterization of the sampling sites, seasonal variability in chlorophyll $a$ (Chl- $a$ ), particulate organic carbon (POC) concentrations and water temperature were recorded at each sampling locality, and contaminant burden analysis (including metals and polycyclic aromatic hydrocarbons [PAHs]) in soft tissues was performed. Regarding biological responses in mussels, changes in adipogranular cell (ADG) density and gamete developmental state were determined as a supporting parameters. At the biochemical level, catalase (CAT), glutathione $S$ transferase activities (GST) and lipid peroxidation (LPO) in the digestive gland, and acetylcholinesterase activity (AChE) in the gills were measured. At cellular level, changes in lysosomal membrane stability (LMS), lysosomal structural changes (LSC), lipofuscin $\left(\mathrm{Vv}_{\mathrm{LPF}}\right)$ and neutral lipid $\left(\mathrm{Vv}_{\mathrm{NL}}\right)$ volume density in the digestive cells of mussels were quantified. Changes in volume density of basophilic cells $\left(\mathrm{Vv}_{\mathrm{BAS}}\right)$, atrophy of the digestive epithelium of the digestive alveoli and connective to digestive tissue ratio (CTD) were calculated in order to determine the responses at the tissue level. In addition, histopathological alterations were examined in the digestive, gonad and gill tissues.

\section{Material and methods}

\subsection{Remote sensing of environmental factors}

In order to provide a regional-scale assessment of the marine environment during the samplings and previous days, Mapped Level-3 MODIS daily data at $4 \mathrm{~km}$ resolution (Aqua and Terra satellites) were downloaded from the NASA Ocean Color servers covering the period from 1st October 2002 to 1st October 2018. The data corresponds to the concentration of photosynthetic chl- $a$ pigment (CHLOR_A, $\mathrm{mg} \mathrm{m}^{-3}$, Hu et al., 2012), and POC ( $\mathrm{mg} \mathrm{m}^{-3}$, Stramski et al., 2008), which are descriptors of phytoplankton biomass and oceanic primary 
production, respectively (Honjo et al., 2008; Raateoja et al., 2018), and daytime and night-time sea surface temperature (SST, Celsius, Kilpatrick et al., 2015) at $11 \mu \mathrm{m}$ wavelength.

The amount of missing data in northern latitudes is very high due to the cloud coverage affecting the atmospheric propagation of infrared radiation. In order to increase the number of pixels available for representing the regional state of the marine environment, daily night-time and daytime satellite SST fields have been averaged instead of focusing on the daytime or night-time alone (Kozlov et al., 2014), since previous studies have shown that the reliability of the SST data over the area is high (She et al., 2007). Satellite-derived daily data have been spatially averaged in boxes around the sampling sites (Fig. 1). In the case of SST, daily daytime and night-time box-averaged data from Aqua and Terra satellites have been averaged, providing individual daily data over the boxes depicted in Fig. 1. For all satelliteretrieved variables, smoothed daily seasonal cycles have been computed by getting the medians corresponding to the set of daily values corresponding to the same Julian Day from the 17 years in the processed period common to the Aqua and Terra satellites. The use of the median instead of the average in this case is justified in order to avoid the noise that appears for some variables (particularly CHLOR_A and POC at the beginning or the end of the sampled period). Daily median-based seasonal cycles are still quite irregular, and they have been smoothed by means of an 11 day running mean that is only computed in case at least $60 \%$ of the days involved in the computation of the running mean are present. This way, the impact of the outliers in the definition of the smoothed seasonal cycle is kept to a minimum. Then, the smoothed seasonal cycles have been used to define daily anomalies of CHLOR_A, POC and SST. Besides the smoothed seasonal cycles, running means (seven days) are used to plot satellite-derived daily values of these variables in Fig. 2.

\subsection{Sampling}

The collection of mussels (Mytilus trossulus) was carried out in the northern (Gulf of Finland; Tvärminne Zoological Station of the University of Helsinki in the Hanko Peninsula 59 $50^{\prime} 45.39^{\prime \prime} \mathrm{N} 23^{\circ} 15^{\prime} 41.81^{\prime \prime} \mathrm{E}$ ) and southwestern (Kiel Fjord $54^{\circ} 22^{\prime} 11.24^{\prime \prime} \mathrm{N} 10^{\circ} 9^{\prime} 17.70^{\prime \prime} \mathrm{E}$ ) part of the Baltic Sea (Fig. 1). Three seasonal samplings were carried out (4th April 2017 Finland, 17th March 2017 Germany, 7th July 2016 Finland, 17th August 2016 Germany and 26th October 2016 Finland, 8th November 2016 Germany).

Due to the lack of tide in the Baltic Sea mussels for research purposes are usually collected by scuba diving, here at the depth of ca. $8 \mathrm{~m}$. Immediately after the dive the mussels were sorted and ca. 100 mussels with a maximum length of $2.5-3.0 \mathrm{~cm}$ were placed to thermo-insulated containers with water from the collection site. The mussels were taken to the laboratory, kept in ambient water and temperature until the next

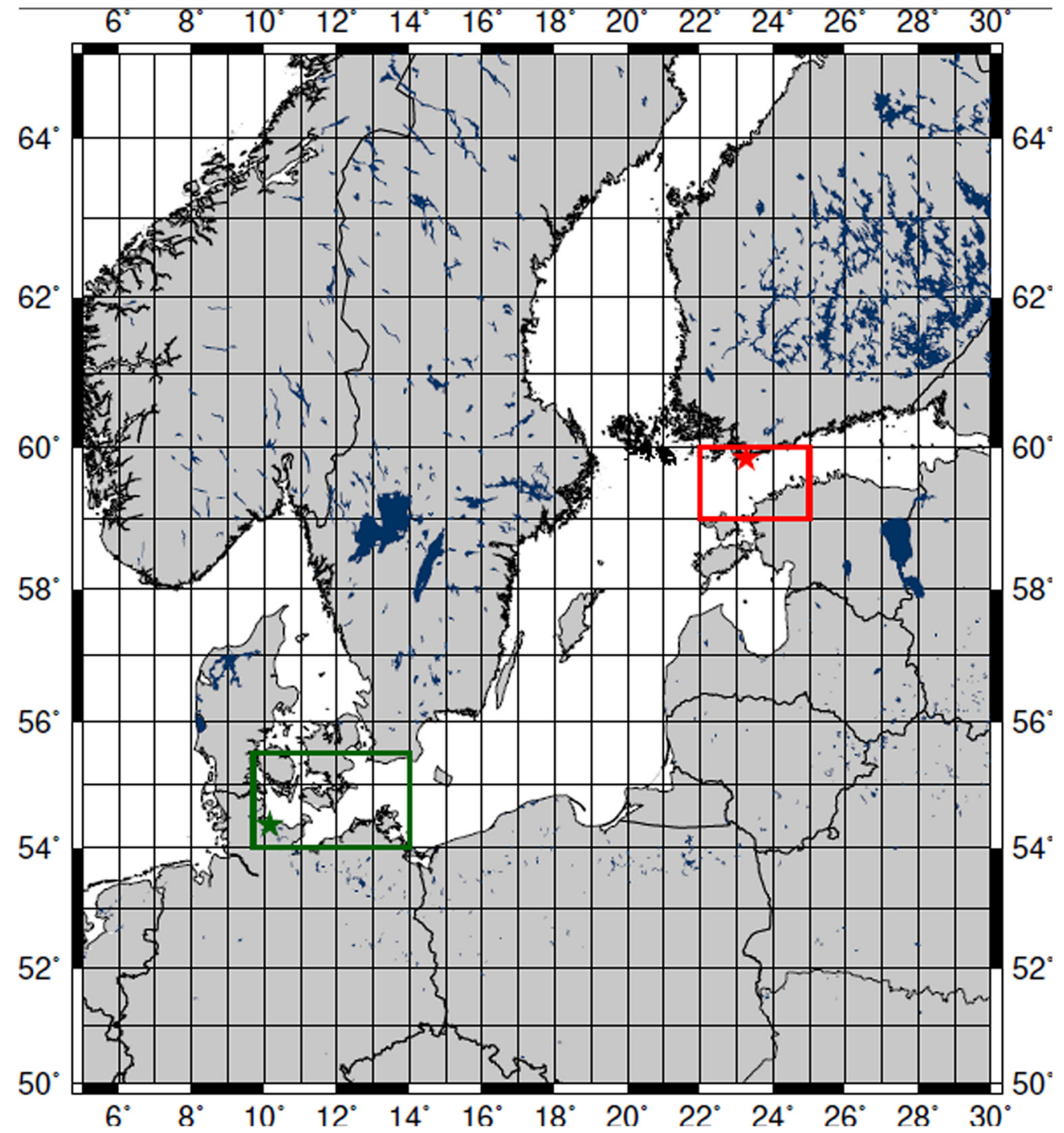

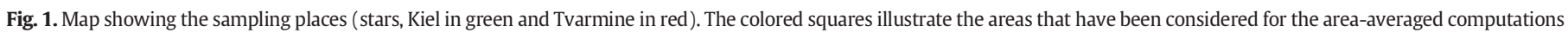
over satellite data. 

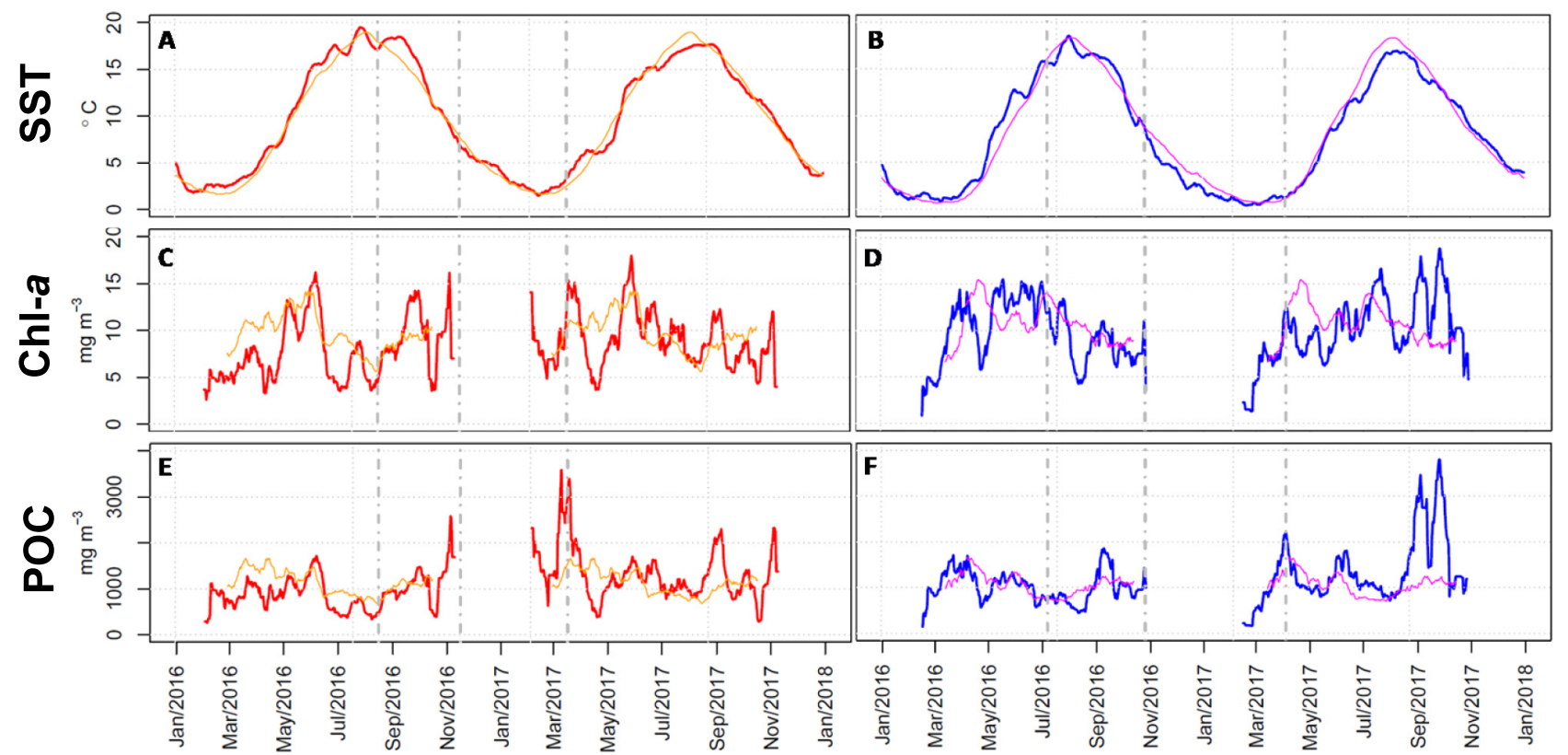

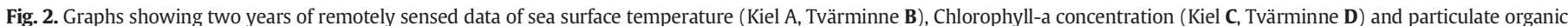

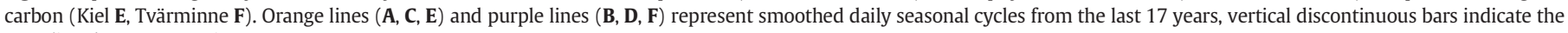
sampling days at every site.

day when dissection took place. Transversal slices including mantle, gills and digestive gland were made for 20 mussels for histopathological analysis and tissue-level biomarkers. Gills, and digestive gland of 30 mussels were dissected and frozen in liquid nitrogen for histochemical and biochemical endpoints. Additional samples of whole mussels were frozen for contaminant analysis of soft tissues.

\subsection{Sample processing}

The transversal slices were fixed in seawater with $4 \%$ formaldehyde, dehydrated in an ethanol bath series, paraffin embedded using a Leica ASP3005 tissue processor and sectioned at $5 \mu \mathrm{m}$ with a Leica RM2125RTS microtome for histopathological analysis and tissue level biomarkers. Each digestive gland was stored frozen at $-80^{\circ} \mathrm{C}$, then sectioned at $8 \mu \mathrm{m}$ with a CM3050s Leica cryotome for histochemical analysis. The frozen gills and digestive glands were used for the biochemical endpoints.

\subsection{PAH tissue burden}

Pooled samples of 30 mussel soft tissue were homogenized and 5-10 g was taken for the extraction of PAHs in one pool from each sampling site and season. Internal (Fluoro-PAHs, Chiron) and yield PAH standards were added to the homogenate. Five milliliter of water and $10 \mathrm{ml}$ of ethylacetate were added and the samples were shaken for $1 \mathrm{~min}$. A salt mixture consisting of $4 \mathrm{~g} \mathrm{MgSO}_{4}$ and $2 \mathrm{~g} \mathrm{NaCl}$ was added. The samples were again shaken for $1 \mathrm{~min}$ and then centrifuged for $10 \mathrm{~min}$. Five milliliter of the ethylacetate extract supernatant was taken and $200 \mu \mathrm{l}$ of isooctane added to the extract. Ethylacetate was evaporated under a nitrogen flow and $1 \mathrm{ml}$ of hexane was added. The extract was purified in a column containing glass wool, $\mathrm{Na}_{2} \mathrm{SO}_{4}$, and silica. The PAH compounds, in hexane, were eluted with hexane/dichloromethane $(3: 1, \mathrm{v} / \mathrm{v})$. After elution $0,5 \mathrm{ml}$ isooctane was added as solvent keeper and the solvent was evaporated under a gentle flow of nitrogen until a final volume of $0.5 \mathrm{ml}$ was reached. Ten microliter of injection standards (deuterated PAHs, Dr. Ehrenstorfer) was added and the sample was analyzed with a Thermo GC-MS/MS (Trace 1310 GC Ultra gas chromatograph and TSQ Quantum XLS ultra mass spectrometer). Measurements were done with selected reaction monitoring (SRM) mode. Identification of the PAH compounds was done selecting two typical fragment ions. Fresh weight units were converted to dry weight units using a correction factor based on the water percentage of soft tissues of mussels (Potrykus et al., 2003).

\subsection{Trace metal tissue burden}

A pool of 20 mussels per site and season was freeze-dried, homogenized, weighed $( \pm 0.0001 \mathrm{~g})$ and transferred to a Teflon lining tube for microwave digestion. On each tube we added $2 \mathrm{ml}$ of $\mathrm{HNO}_{3}(69 \%$, Tracepur, Merck), $2 \mathrm{ml}$ of $\mathrm{H}_{2} \mathrm{O}_{2}$ (30\% Fluka, p.a.) and $2 \mathrm{ml}$ of MilliQ water (Millipore Element). The tubes were mounted on the passive heating cylinder and closed with Teflon caps.

The microwave heating program had been optimized previously and followed a power programmed path (Anton Paar, Multiwave Pro). The first step was to increase the power to $600 \mathrm{~W}$ in $5 \mathrm{~min}$ (min) and keep there for 5 more min. The power was then increased up to $1000 \mathrm{~W}$ in $5 \mathrm{~min}$ and kept for $5 \mathrm{~min}$. Finally, the power was switched off $(0 \mathrm{~W})$ and the oven was pressurized to cool down the sample (15 min). During this program the typical highest pressure and temperature were around 20 bar and $190^{\circ} \mathrm{C}$ and the digestion of biological tissues was usually completed thoroughly. The rotor allowed the digestion of 8 samples simultaneously but two of them were systematically reserved to blank analysis.

The extract was transferred to a syringe barrel and filtered through a PVDF $0.45 \mu \mathrm{m}$ disk filter. All the Teflon lining tubes and caps were rinsed with MilliQ water and filtered in the same way. The final solution was prepared in accurately weighed Falcon tubes and MilliQ water was added up to $50 \mathrm{ml}$. The final Falcon tubes were weighed to get the exact mass of solution. Finally, all the solutions were diluted to match the final acidity with that of the standard solutions $(<1 \%)$.

The elemental analysis was carried out by ICP-MS (NexIon200, Perkin Elmer). The samples were sipped with a peristaltic pump to the nebulisation system (Meinhard nebuliser) and simultaneously through a parallel line a continuous flow of internal standards solution (Ge, Sc 
and $\mathrm{Y}$ ) was mixed and measured to overcome measurement drifts. The following isotopes were measured ${ }^{7} \mathrm{Li},{ }^{27} \mathrm{Al},{ }^{88} \mathrm{Sr},{ }^{98} \mathrm{Mo},{ }^{107} \mathrm{Ag},{ }^{120} \mathrm{Sn}$, ${ }^{121} \mathrm{Sb},{ }^{137} \mathrm{Ba},{ }^{184} \mathrm{~W},{ }^{205} \mathrm{Tl}$ and ${ }^{206+207+208} \mathrm{~Pb}$ (Internal standards: $\mathrm{Sc}$, In and Bi) standard mode. ${ }^{47} \mathrm{Ti},{ }^{51} \mathrm{~V},{ }^{52} \mathrm{Cr},{ }^{55} \mathrm{Mn},{ }^{56} \mathrm{Fe},{ }^{59} \mathrm{Co},{ }^{60} \mathrm{Ni},{ }^{63} \mathrm{Cu}$, ${ }^{66} \mathrm{Zn},{ }^{75} \mathrm{As},{ }^{78} \mathrm{Se}{ }^{111} \mathrm{Cd}$ and ${ }^{202} \mathrm{Hg}$ (Internal standards Sc, Y, Ge and In) He collision mode. Although in many studies a smaller set of metals are usually considered, all these were measured since they were already included in the routine procedures of the analysing laboratory (Rodriguez-Iruretagoiena et al., 2016).

\subsection{Adipogranular cell index}

As an indicator of the reserve energy material in the mantle, the adipogranular (ADG) cell index can give a hint of the metabolic strategy related to reproduction and seasonal bioenergetic changes (Bignell et al., 2008). Adipogranular cells of the mantle contain glycogen, lipids and proteins (Danton et al., 1996), and it the density of these cells has been shown to be inversely proportional to the amount of germinal tissue in the mantle (Moukrim et al., 2008). Assessment of ADG cell density was carried out as described $(n=20)$ by Bignell et al. (2008) in histological preparations (see Section 2.10) using a grading system, where 0 means no ADG cells apparent within vesicular connective tissue, 1 means ADG cells can be seen but they appear to be scarce, 2 means ADG cells appear scattered throughout mantle tissue, 3 means there is a marked increase in the abundance of ADG cells and some areas may not appear to show absolute consistency, and 4 means ADG cells can be seen to constitute the majority of connective tissue volume.

\subsection{Gamete development}

Gamete developmental stages were determined in histological preparations (see Section 2.10) $(n=10)$ as described by Ortiz-Zarragoitia et al. (2011) and were distinguished in mussel gonads as follows: resting stage (inactive or undifferentiated); early gametogenic stage (gametogenesis has begun but no ripe gametes visible); advanced gametogenic stage (gametogenesis still progressing and ripe gametes and developing gametes have about equal proportions); mature stage (gonad fully mature, follicles full of ova or sperm); spawning stage (active emission of gametes, some follicles appear empty); post-spawning stage (empty follicles and only residual gametes remain).

\subsection{Biochemical biomarkers}

Digestive glands of 15 mussels from each location and time point were homogenized in $100 \mathrm{mM}$ potassium phosphate buffer ( $\mathrm{pH} 7.4$ ). Samples of the homogenate were taken for LPO analysis and 4\% BHT was added to inhibit peroxidation. The rest of the homogenate was centrifuged at $10.000 \mathrm{~g}$ for $20 \mathrm{~min}$ at $4{ }^{\circ} \mathrm{C}$ and the supernatants were stored at $-80^{\circ} \mathrm{C}$ until analysis. Gills of 30 mussels from each location and time point were homogenized in $20 \mathrm{mM}$ sodium phosphate buffer containing $0.1 \%$ Triton $\mathrm{X}$ ( $\mathrm{pH} 7.0$ ), centrifuged at $10000 \mathrm{~g}$ for $20 \mathrm{~min}$ at $4{ }^{\circ} \mathrm{C}$. The supernatants were stored at $-80^{\circ} \mathrm{C}$ until analysis. All enzyme activities were measured in 96-well plates using a microplate reader (TECAN Infinite 200) and analyzed using Magellan software (TECAN). The digestive gland samples were analyzed for GST, CAT and LPO, and the gill samples for AChE. Protein concentrations were determined using the Bradford (1976) method with a bovine serum albumin standard (Sigma A7030).

GST activity is a biomarker of exposure to, e.g., polycyclic aromatic hydrocarbons (PAH) and polychlorinated biphenyls (PCB) both in fish and invertebrates (Leiniö and Lehtonen, 2005). It was measured as the formation rate of the conjugated substrate chlorodinitrobenzeneglutathione (CDNB-GSH) at $340 \mathrm{~nm}$, according to Habig et al. (1974). Concentrations of $1 \mathrm{mM}$ of both CDNB (Sigma-Aldrich 138630) and GSH (Sigma-Aldrich G4251) in $100 \mathrm{mM}$ potassium phosphate buffer, $\mathrm{pH} 7.0$, were used in the reaction.
CAT activity, indicator of oxidative stress caused by exposure to e.g. trace metals, has recently been studied in aquatic organisms including bivalves (Leiniö and Lehtonen, 2005). It was measured as degradation of hydrogen peroxide $\left(\mathrm{H}_{2} \mathrm{O}_{2}\right.$, Fluka 95302) mediated by CAT at $240 \mathrm{~nm}$ (Claiborne, 1985). The final concentration of $\mathrm{H}_{2} \mathrm{O}_{2}$ in the reaction was $4.3 \mathrm{uM}$ in $100 \mathrm{mM}$ potassium phosphate buffer, $\mathrm{pH}$ 7.0.

LPO level is an indicator of oxidative damage (Shaw et al., 2004) and was measured as thiobarbituric acid reactive substances at $535 \mathrm{~nm}$ (Ohkawa et al., 1979). The reaction mixture contained $60 \mathrm{mM}$ Tris- $\mathrm{HCl}$ with diethylenetriaminepentaacetic acid (DTPA, Sigma-Aldrich D6518), $0.24 \mathrm{M}$ trichloroacetic acid (Sigma-Aldrich T6399) and $16 \mathrm{mM} 2$ thiobarbituric acid (Sigma-Aldrich T5500).

The responsiveness of AChE activity to chemicals such as metals, detergents and algal toxins has also been acknowledged and indicates neurotoxic stress (Leiniö and Lehtonen, 2005). AChE activity was determined by measuring the hydrolysis of acetylthiocholine (ACTC) at $412 \mathrm{~nm}$ (Bocquené and Galgani, 1998). The reaction mixture contained $0.57 \mathrm{mM}$ of 5,5' dithiobis 2 nitrobenzoic acid (DTNB, Sigma D8130) and $2.9 \mathrm{mM}$ of acetylthiocholine iodide (Sigma A5751) in $20 \mathrm{mM}$ sodium phosphate buffer ( $\mathrm{pH} 7.0$ ).

\subsection{Cellular biomarkers}

LMS and LSC are general stress biomarkers (Marigómez et al., 2006; Izagirre et al., 2008). The determination of LMS was based on the time of acid labilisation treatment required to produce the maximum staining intensity according to UNEP/RAMOGE (1999) after the demonstration of hexosaminidase (Hex) activity in digestive cell lysosomes. Slides (10 digestive glands per group) were put at $4{ }^{\circ} \mathrm{C}$ for $30 \mathrm{~min}$ and then $10 \mathrm{~min}$ at room temperature prior to staining. Serial cryotome sections $(10 \mu \mathrm{m})$ were subjected to acid labilisation in intervals of $0,3,5,10,15$, $20,25,30,35$ and $40 \mathrm{~min}$ in $0.1 \mathrm{M}$ citrate buffer ( $\mathrm{pH} 4.5$ containing $2.5 \%$ $\mathrm{NaCl}$ ) in a shaking water bath at $37^{\circ} \mathrm{C}$, in order to find out the range of pre-treatment time needed to completely labilise the lysosomal membrane. Following this treatment, sections were transferred to the substrate incubation medium for the demonstration of Hex activity, consisting of $20 \mathrm{mg}$ naphthol AS BI $N$ acetyl b D glucosaminide (Sigma, $\mathrm{N} 4006$ ) dissolved in $2.5 \mathrm{ml}$ of 2 methoxyethanol (Merck, 859), and made up to $50 \mathrm{ml}$ with $0.1 \mathrm{M}$ citrate buffer ( $\mathrm{pH} 4.5$ ) containing $2.5 \%$ $\mathrm{NaCl}$ and $3.5 \mathrm{~g}$ of low viscosity polypeptide (Sigma, P5115) to act as a section stabiliser. Sections were incubated in this medium for $20 \mathrm{~min}$ at $37{ }^{\circ} \mathrm{C}$, rinsed in a saline solution $(3.0 \% \mathrm{NaCl})$ at $37 \mathrm{C}$ for $2 \mathrm{~min}$ and then transferred to $0.1 \mathrm{M}$ phosphate buffer ( $\mathrm{pH} 7.4$ ) containing $1 \mathrm{mg} / \mathrm{ml}$ of diazonium dye Fast Violet B salt (Sigma, F1631), at RT for $10 \mathrm{~min}$. Slides were then rapidly rinsed in running tap water for 5 min, fixed for 10 min in Baker's formol calcium containing 2.5\% $\mathrm{NaCl}$ at $4 \mathrm{C}$ and rinsed in distilled water. Finally, slides were mounted in Kaiser's glycerine gelatine and sealed with nail varnish. The time of acid labilisation treatment required to produce the maximum staining intensity was assessed under the light microscope as the maximal accumulation of reaction product associated with lysosomes (UNEP/ RAMOGE, 1999). Four determinations were made for each animal by dividing each section in the acid labilisation sequence into four approximately equal segments and assessing the labilisation period in each of the corresponding set of segments. The mean value was then derived for each section, corresponding to an individual digestive gland.

The histochemical activity of $\beta$ glucuronidase was demonstrated in unfixed cryotome sections (10 digestive glands per group) as in Moore (1976). Sections ( $8 \mu \mathrm{m}$ ) were cut in a CM3050 cryotome at a cabinet temperature of $-25^{\circ} \mathrm{C}$, collected into warm glass slides and stored at $-40{ }^{\circ} \mathrm{C}$ until required for staining. Sections were tempered at room temperature for $5 \mathrm{~min}$ and then transferred to the substrate incubation medium consisting of $22.4 \mathrm{mg}$ of naphthol AS-BI- $\beta$-D-glucuronide dissolved in $0.96 \mathrm{ml}$ sodium bicarbonate $(50 \mathrm{mM})$ and made up to $80 \mathrm{ml}$ with $0.1 \mathrm{M}$ acetate buffer ( $\mathrm{pH} 4.5$ ) containing $2.5 \% \mathrm{NaCl}$ and $12 \mathrm{~g}$ of polyvinyl at a $20 \%(\mathrm{w} / \mathrm{v})$ concentration as colloid stabiliser. Sections were 
incubated for $20 \mathrm{~min}$ at $37^{\circ} \mathrm{C}$ in a water bath with constant agitation. Then slides were rinsed in $2.5 \% \mathrm{NaCl}$ at $37{ }^{\circ} \mathrm{C}$ for $2 \mathrm{~min}$ and stained at room temperature for $10 \mathrm{~min}$ and in darkness, with $1 \mathrm{mg} / \mathrm{ml}$ fast garnet $\mathrm{GBC}$ in $0.1 \mathrm{M}$ phosphate buffer ( $\mathrm{pH} 7.4$ ) plus $2.5 \% \mathrm{NaCl}$. Sections were then fixed in Baker's calcium formol (4\% formaldehyde, 1\% calcium chloride, $2.5 \%$ sodium chloride) for $10 \mathrm{~min}$ at $4{ }^{\circ} \mathrm{C}$ and rinsed in distilled water. Finally, sections were gently washed in distilled water and mounted in Kaiser's gelatine.

A stereological procedure was applied to quantify the structure of the digestive cell lysosomes in mussels, using an image analysis system. The system consists of a B\&W-CCD video camera, a Leitz Laborlux light microscope, a computer with video board and BMS software. An objective lens of $100 \times$ magnification was used. Binary images segregating lysosomes from digestive cell cytoplasm were obtained by the segmentation procedure, which was manually adjusted in the first measurement of a given section to correct slight differences in staining intensity between different sections. With the image analysis system lysosomal volume density $\left(\mathrm{Vv}_{\mathrm{LYS}}\right)$, lysosomal surface-to-volume ratio $\left(\mathrm{S} / \mathrm{V}_{\mathrm{LYS}}\right)$ and lysosomal numerical density $\left(\mathrm{Nv}_{\mathrm{LYS}}\right)$ were generated. Five measurements were made per digestive gland. The stereological formulae include a correction factor for particles with an average diameter smaller than the section thickness (Lowe et al., 1981). Sample size was determined based on previous analyses of mean and standard deviation values of the four parameters which at least resulted to keep constant for a sampling area over 16,000 $\mathrm{mm}^{2}$ (Etxeberria et al., 1994). Since the total area of digestive cells scanned in each measurement was approximately $4000 \mu^{2}, 5$ measurements were made on one single section (total sampling area per mussel $20,000 \mu \mathrm{m}^{2}$ ).

Lipofuscins are considered as end products of lipid peroxidation or digestion (Cheung et al., 2001). Likewise, increased lipofuscin concentrations have been linked to oxidative damage (Viarengo et al., 1991) and digestive impairment (Benito et al., 2017) in the digestive gland of molluscs. The Schmorl method (Pearse, 1985) was used to detect lipofuscins. Sections $(8 \mu \mathrm{m})$ were cut in a CM3050S Leica cryotome at a cabinet temperature of $-25^{\circ} \mathrm{C}$, collected into warm glass slides and stored at $-40^{\circ} \mathrm{C}$ until required for staining. The slides (10 digestive glands per group) were fixed in Baker's formol calcium containing $2.5 \% \mathrm{NaCl}$ for $15 \mathrm{~min}$ at $4{ }^{\circ} \mathrm{C}$. After rinsing the sections in distilled water they were immersed in the reaction medium containing $1 \%$ ferric chloride and $1 \%$ potassium ferricyanide in a ratio of $3: 1$ for $5 \mathrm{~min}$. The sections were then rinsed in $1 \%$ acetic acid for $1 \mathrm{~min}$. Finally, the sections were rinsed in distilled water and mounted with Kaiser's glycerin gelatin. $\mathrm{Vv}_{\mathrm{LPF}}$ was quantified in respect to cytosol volume density by using BMS software as explained before to quantify the structure of the digestive cell lysosomes, $\times 40$ magnification objective was used. $V_{v_{L P F}}$ was calculated as the ratio between lipofuscin volume and cytosol volume
$\left(\mathrm{VV}_{\mathrm{LPF}}=\mathrm{V}_{\mathrm{LPF}} / \mathrm{V}_{\mathrm{C}}\right)$ where $\mathrm{V}_{\mathrm{LPF}}=$ volume of lipofuscins and $\mathrm{V}_{\mathrm{C}}=$ volume of cytosol.

Intracellular NL accumulation in digestive gland has been related to organic xenobiotic exposure, non-specific stress and nutritional status (Cancio et al., 1999; Marigómez and Baybay-Villacorta, 2003; Shaw et al., 2011). The determination of NL content was performed for frozen $8 \mu \mathrm{m}$ thickness sections from the digestive glands $(n=10)$, which were obtained in the cryostat at $-25{ }^{\circ} \mathrm{C}$ chamber temperature. The slides were stored at $-40{ }^{\circ} \mathrm{C}$ and stained following Lillie and Ashburn's Oil Red O (ORO) method (Culling, 1974). $\mathrm{Vv}_{\mathrm{NL}}$ was quantified in respect to connective tissue by using BMS software (see beforehand), the $\times 40$ magnification objective was used. $\mathrm{Vv}_{\mathrm{NL}}$ was calculated as the ratio between neutral lipid volume and connective tissue volume $\mathrm{Vv}_{\mathrm{NL}}=\mathrm{V}_{\mathrm{NL}}$ $/ \mathrm{V}_{\mathrm{CT}}$, where $\mathrm{V}_{\mathrm{NL}}=$ volume of neutral lipids and $\mathrm{V}_{\mathrm{CT}}=$ volume of connective tissue (Marigómez and Baybay-Villacorta, 2003).

\subsection{Tissue-level biomarkers and histopathology}

Paraffin sections $(5 \mu \mathrm{m})$ were stained with haematoxylin-eosin $(\mathrm{H} /$ E) in order to analyze the integrity of the digestive gland, gonad and gills. $\mathrm{Vv}_{\mathrm{BAS}}$ is a general stress biomarker that measures the relative increase of basophilic cells under stress conditions in the digestive alveoli of molluscs (Zorita et al., 2006; Rementeria et al., 2016; Benito et al., 2017). A high CTD ratio indicates a loss of the integrity of the digestive gland of molluscs, and it can be caused by a chemical stressor or by an insufficient nutritive status (Mújica et al., 2015b; Benito et al., 2017).

$\mathrm{Vv}_{\mathrm{BAS}}$ and CTD were quantified $(n=10)$ by means of stereology as an indication of whether changes in cell-type composition and in the amount connective tissue occurred or not. Counts were made in three randomly selected fields in one digestive gland slide per mussel (10 mussels per sample). Slides were viewed at $40 \times$ objective (final magnification $\sim 400 \times$ ) using a drawing tube attached to a light microscope. A simplified version of the Weibel graticule multipurpose test system M-168 (Weibel, 1979) was used, and hits on basophilic cells (b), digestive cells (d), diverticular lumens (1) and interstitial connective tissue (c) were recorded. $V v_{\text {BAS }}$ was calculated according to the Delesse's principle (Weibel, 1979), as $V_{V_{B A S}}=$ VBAS / VEP, where VBAS is the volume of basophilic cells and VEP the volume of digestive gland epithelium. CTD ratio was calculated as CTD $=c /(b+d+1)$.

Epithelial thinning of the digestive alveoli of mussels measured as atrophy index can be an indicative of general stress (Kim et al., 2006; Garmendia et al., 2011). The severity of the atrophy index of the digestive alveoli was rated using a numerical grading from 0 to $4(n=20)$ as described by Kim et al. (2006), where 0 means normal digestive diverticula with nearly occluded lumen; 1 means co-occurrence of normal and partially atrophied tubules of epithelium thickness greater than

Table 1

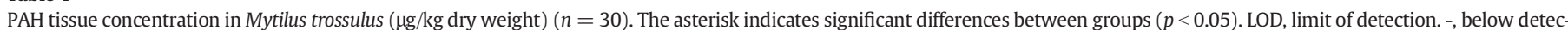
tion limit.

\begin{tabular}{|c|c|c|c|c|c|c|c|}
\hline & LOD & Kiel summer & Kiel autumn & Kiel spring & Tvärminne summer & Tvärminne autumn & Tvärminne spring \\
\hline Anthracene & 9 & - & - & - & - & - & - \\
\hline Acenaphtene & 9 & - & - & - & - & - & - \\
\hline Acenaphtylene & 9 & - & - & - & - & - & - \\
\hline Benz(a)anthracene & 18 & - & 18.9 & - & - & - & - \\
\hline Benzo(a)pyrene & 18 & - & & - & - & - & - \\
\hline Benzo(b)fluoranthene & 18 & - & 22.5 & - & - & - & - \\
\hline Benzo(ghi)perylene & 18 & - & - & - & - & - & - \\
\hline Benzo(k)fluoranthene & 18 & - & - & - & - & - & - \\
\hline Dibenz(a,h)anthracene & 18 & - & - & - & - & - & - \\
\hline Phenantrene & 9 & - & 18 & 11.7 & & - & - \\
\hline Fluoranthene & 9 & 17.1 & 63.9 & 36 & 9.9 & - & 14.4 \\
\hline Fluorene & 9 & - & - & - & - & - & - \\
\hline Indeno( $1,2,3 \mathrm{~cd})$ pyrene & 18 & - & - & - & - & - & - \\
\hline Chrysene & 18 & - & - & - & - & - & - \\
\hline Pyrene & 18 & 15.3 & 48.6 & 22.5 & - & - & 12.6 \\
\hline$\sum \mathrm{PAHs}$ & & 32.4 & $171.9^{*}$ & 70.2 & 9.9 & - & 45 \\
\hline
\end{tabular}


Table 2

Metal tissue concentration in Mytilus trossulus ( $\mu \mathrm{g} / \mathrm{g}$ dry weight) $(n=20)$. The asterisk indicates significant differences between groups $(p<0.05)$.

\begin{tabular}{lllllll}
\hline & $\begin{array}{l}\text { Kiel } \\
\text { summer }\end{array}$ & $\begin{array}{l}\text { Kiel } \\
\text { autumn }\end{array}$ & $\begin{array}{l}\text { Kiel } \\
\text { spring }\end{array}$ & $\begin{array}{l}\text { Tvärminne } \\
\text { summer }\end{array}$ & $\begin{array}{l}\text { Tvärminne } \\
\text { autumn }\end{array}$ & $\begin{array}{l}\text { Tvärminne } \\
\text { spring }\end{array}$ \\
\hline $\mathrm{Li}$ & 0.36 & 0.28 & 0.37 & 0.27 & 0.22 & $0.09^{*}$ \\
$\mathrm{Al}$ & 44.63 & 52.58 & 37.67 & $113.10^{*}$ & 81.36 & 30.18 \\
$\mathrm{Sr}$ & 23.69 & 18.35 & 26.35 & $50.54^{*}$ & 37.98 & 26.27 \\
$\mathrm{Mo}$ & 0.46 & 0.48 & 0.47 & 0.58 & 0.60 & 0.39 \\
$\mathrm{Ag}$ & 0.03 & 0.02 & 0.02 & 0.05 & 0.06 & 0.04 \\
$\mathrm{Sn}$ & 0.17 & 0.22 & 0.11 & 0.08 & 0.037 & 0.01 \\
$\mathrm{Sb}$ & 0.02 & 0.03 & 0.02 & 0.02 & 0.01 & 0.01 \\
$\mathrm{Ba}$ & 10.75 & 6.39 & 2.07 & 8.87 & 5.86 & 3.35 \\
$\mathrm{~W}$ & 0.03 & 0.03 & 0.02 & $0.04^{*}$ & 0.09 & 0.02 \\
$\mathrm{Hg}$ & $0.31^{*}$ & 0.19 & 0.22 & 0.20 & 0.16 & 0.11 \\
$\mathrm{Tl}$ & 0.01 & 0.01 & 0.01 & 0.01 & 0.01 & 0.01 \\
$\mathrm{~Pb}$ & 1.53 & 0.98 & 1.11 & 0.70 & 0.61 & 0.41 \\
$\mathrm{Ti}$ & 10.96 & 10.52 & 13.77 & 19.78 & 17.64 & 10.86 \\
$\mathrm{Co}$ & 0.43 & 0.26 & 0.25 & 0.49 & 0.41 & 0.27 \\
$\mathrm{Cu}$ & 8.25 & 6.43 & 6.66 & 8.08 & 6.94 & 6.67 \\
$\mathrm{Zn}$ & $121.40^{*}$ & 92.22 & 96.28 & 76.82 & 89.17 & 69.64 \\
$\mathrm{As}$ & 5.50 & 5.49 & 7.47 & 9.60 & 9.37 & 6.08 \\
$\mathrm{Cd}$ & 0.63 & 0.48 & 0.47 & 1.21 & 1.00 & 0.59 \\
$\mathrm{~V}$ & 0.51 & 0.83 & 0.58 & 0.48 & 0.53 & 0.18 \\
$\mathrm{Cr}$ & 0.45 & 0.41 & 0.41 & 0.91 & 0.78 & 0.40 \\
$\mathrm{Mn}$ & $114.52^{*}$ & 27.54 & 25.33 & 53.34 & 27.98 & 22.88 \\
$\mathrm{Fe}$ & 211.08 & 219.52 & 160.75 & 312.49 & 288.30 & 155.43 \\
$\mathrm{Ni}$ & 2.13 & 1.32 & 0.92 & 2.39 & 2.14 & 1.31 \\
$\mathrm{Se}$ & 2.29 & 2.11 & 2.17 & 2.11 & 2.02 & 1.85 \\
\hline & & & & & &
\end{tabular}

one-half of normal; 2 means digestive epithelium thickness half of normal; 3 means significantly atrophied tubules with digestive epithelium less than half as thick as normal, and 4 means that digestive epithelium is extremely thin and nearly all tubules are affected.

Regarding histopathological analyses, slides of 20 mussels per sampling campaign were examined individually under the light microscope using $10 \times, 20 \times$ or $40 \times$ objective lenses. Quantitative scores were made (results not shown) by keeping a running count of the incidences as the slide was scanned to avoid re-examination of each slide multiple times for each category. The prevalence of digenean parasites, MPX intracellular ciliates and rickettsia like organisms was analyzed. In addition, the prevalence of certain tissue conditions was analyzed, including cases of haemocytic infiltration, without distinction between focal and diffuse, granulocytomas and brown cell (ceroid bodies or pigment cells) aggregates and follicular atresia.

\subsection{Integrated biomarker response index (IBR/n)}

IBR index was based on the integration of five biological responses from biochemical to tissue levels (CAT, LPO, $\mathrm{Vv}_{\mathrm{NL}}, \mathrm{VV}_{\mathrm{BAS}}$ and CTD) in order to represent responses at different biological organization levels, according to Beliaeff and Burgeot (2002), Broeg and Lehtonen (2006), and Marigómez et al. (2013). Calculations were based on a multivariate graphic method, according to the following procedure: (1) calculation of the mean and standard deviation for each sample; (2) standardization of data for each sample: $\mathrm{x}_{\mathrm{i}}{ }^{\prime}=\left(\mathrm{x}_{\mathrm{i}}-\mathrm{x}\right) / \mathrm{s}$; where, $\mathrm{x}_{\mathrm{i}}{ }^{\prime}=$ standardized value of the biomarker; $x_{i}=$ mean value of a biomarker from each sample; $x$ $=$ general mean value of $x_{i}$ calculated from all compared samples (data set); $\mathrm{s}=$ standard deviation of $\mathrm{x}_{\mathrm{i}}$ calculated from all samples; ( 3 ) addition of the standardized value obtained for each sample to the absolute standardized value of the minimum value in the data set: $y_{i}=x_{i}{ }^{\prime}+1$ $\mathrm{x}_{\min }{ }^{\prime} \mid$; (4) calculation of the radar plot triangular areas as $A_{i}=(0.59 \times$ $\left(\mathrm{y}_{\mathrm{i}} \times \mathrm{y}_{\mathrm{i}}+1\right) / 2$, where " $\mathrm{y}_{\mathrm{i}}$ " and " $\mathrm{y}_{\mathrm{i}+1}$ " are the standardized values of each biomarker and its next one in the radar plot, respectively, and 0.59 is $\sin \alpha$ ( $\alpha$ : radial angle for a pentagonal radar plot; $\alpha=2 \pi / 5)$; and (5) calculation of the IBR index which is the summing-up of all the radar plot triangular areas ( IBR $=\Sigma A_{i}$ ) (Beliaeff and Burgeot, 2002). Since the IBR value is directly dependent on the number of biomarkers in the data set, the obtained IBR value was divided by the number of biomarkers used to calculate IBR/n (Broeg and Lehtonen, 2006).

\subsection{Statistics}

Statistical analysis was carried out with the aid of the SPSS/PC+ statistical package V.24 (SPSS Inc., Microsoft Co.). For the quantitative data which passed normality test, one-way ANOVA and subsequent Duncan's post-hoc test for multiple comparisons between pairs of mean values was applied $(p<0.05)$. For the semiquantitative results obtained and the quantitative results which did not pass normality test, non-parametric Kruskal-Wallis tests were carried out comparing the variances between sampling sites and seasons $(p<0.05)$. To compare chemical tissue burden, prevalence of histopathological alterations and IBR/n values among sampling sites and seasons, $Z$-score was used $(p<0.05)$. The satellite data were processed using the $\mathrm{R}$ system $(\mathrm{R}$ Core Team, 2018).

\section{Results}

\subsection{Remote sensing of environmental factors}

SST measurements showed that in summer the temperatures were similar in Kiel (Fig. 2A) and Tvärminne (Fig. 2B). Before the summer 2016 sampling the temperatures in Kiel were, on average, stable for ca. a month while in Tvärminne the SST was still increasing the month before the collection. The autumn sampling in Kiel was carried out when the temperatures were already lower than in the autumn sampling in Tvärminne. In spring 2017 the STT in Kiel was slightly higher and already increasing when the mussels were collected while in Tvärminne it had not yet started to rise substantially at the time of sampling.

In summer, the chl- $a$ concentration during the days preceding the mussel collection was low in Kiel (slightly lower than in the historical series) (Fig. 2C) while in Tvärminne the summer sampling was performed after a continuous period of high chl- $a$ concentrations (higher compared to the typical seasonal values) (Fig. 2D). In Kiel, the seasonal peak in chl-a concentrations was registered in autumn while in Tvärminne it occurred just before the autumn sampling. During the spring sampling in Kiel a drastic increase of chl- $a$ was recorded, the values for this period being higher than those in the smoothed seasonal cycle derived from the 17-year record. In Tvärminne, the spring sampling was performed during the first chl- $a$ peak of the year.

In Kiel, the concentration of POC in summer was lower than normally recorded according to the multiyear seasonal cycle (Fig. 2E). In Tvärminne they were similar to the ones commonly registered at that time of the year (Fig. 2F). In Kiel, an increase in POC levels occurred in autumn while in Tvärminne only a slight increase could be seen before the autumn sampling. The highest levels of POC in Kiel were observed close to the spring sampling and were much higher than the values of the smoothed seasonal cycle. In Tvärminne, a peak in the concentration of POC was detected in spring at the time of mussel collection, slightly earlier than the peak that can be seen during most years.

\subsection{PAH tissue burden}

The tissue burden of single PAHs was mostly below or very close to the detection limits of the compounds (Table 1). PAHs presenting the highest concentrations were fluoranthene and pyrene, although the highest values were not statistically different compared to the samples showing lower concentrations. The sum of the measured 15 PAHs was significantly higher in mussels collected from Kiel in autumn compared to all the other samples. 

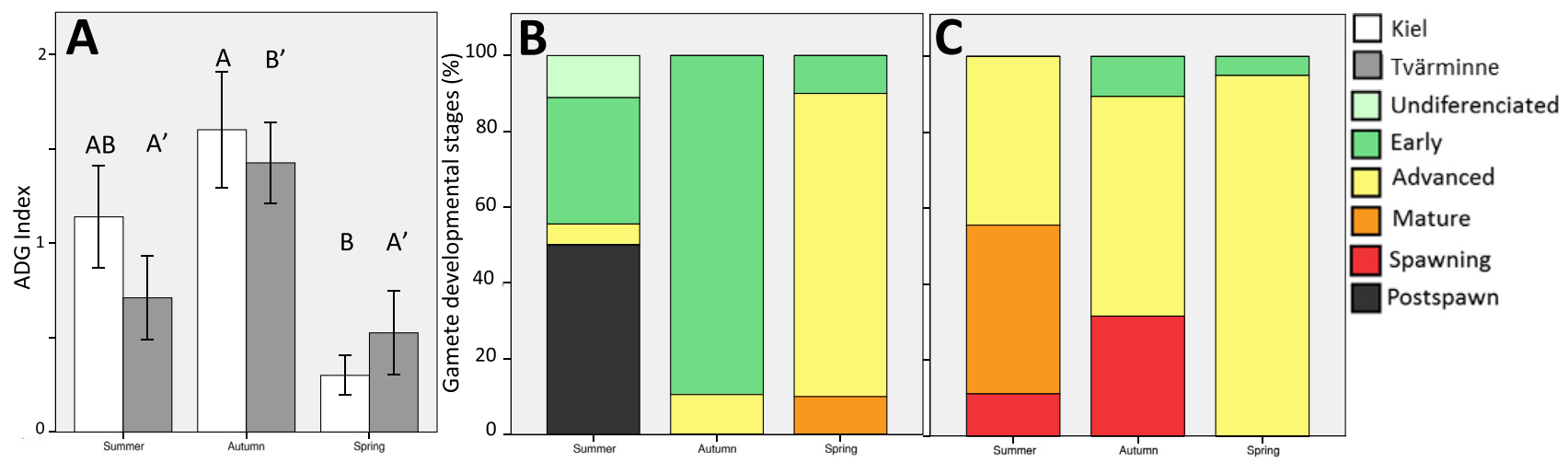

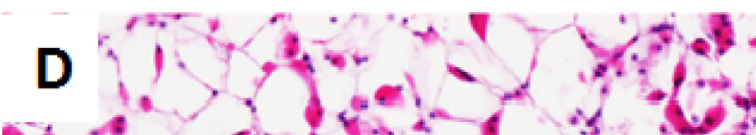

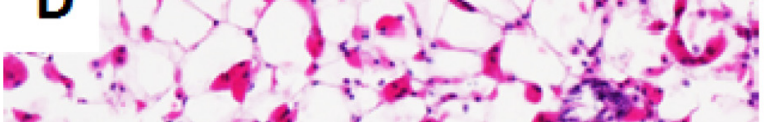

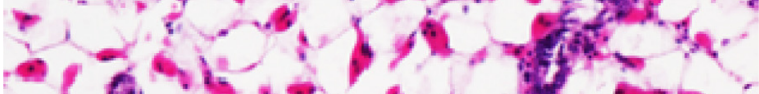

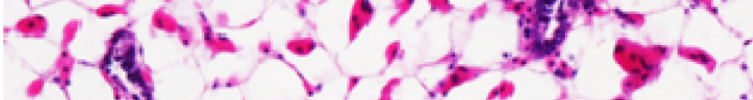

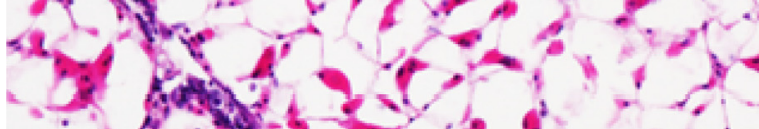

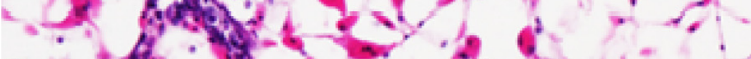

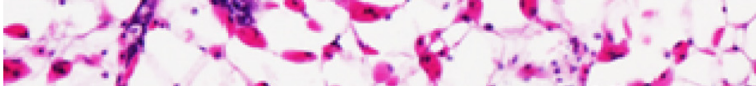

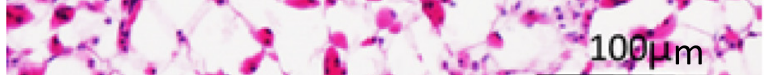

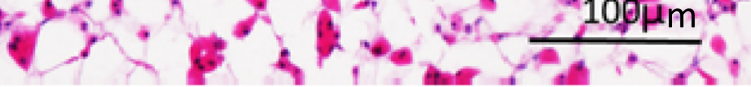
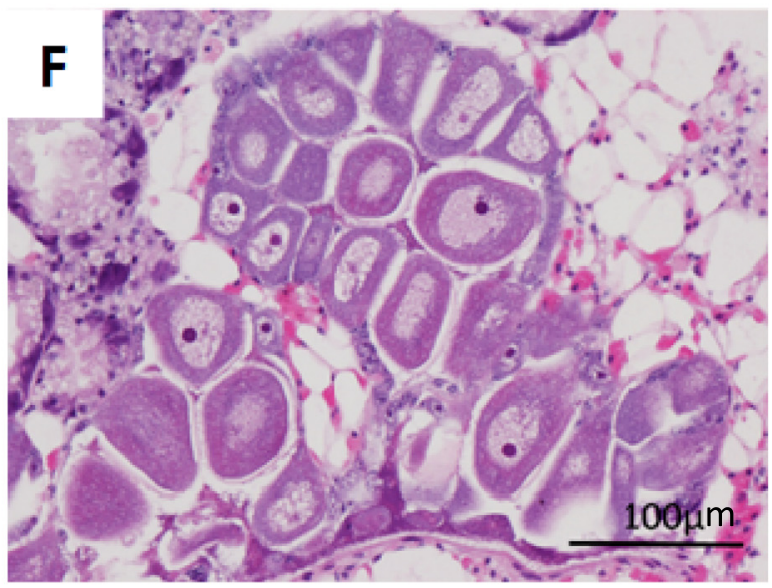

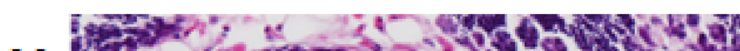
$\mathrm{H}$ \% fores?

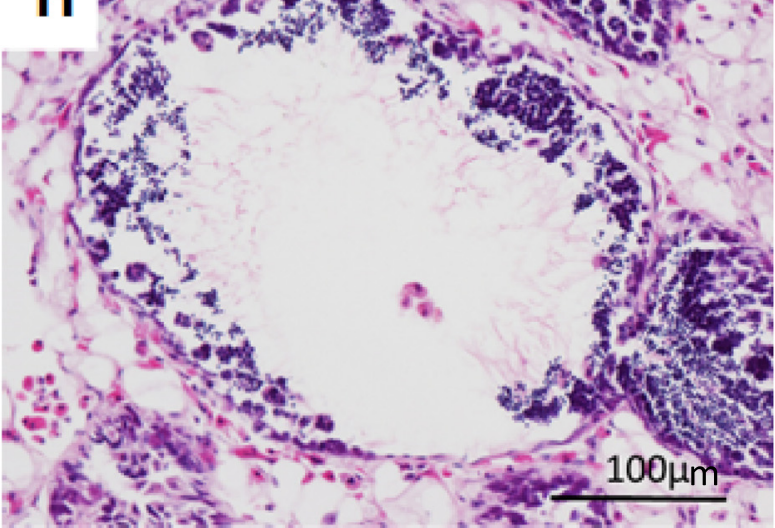
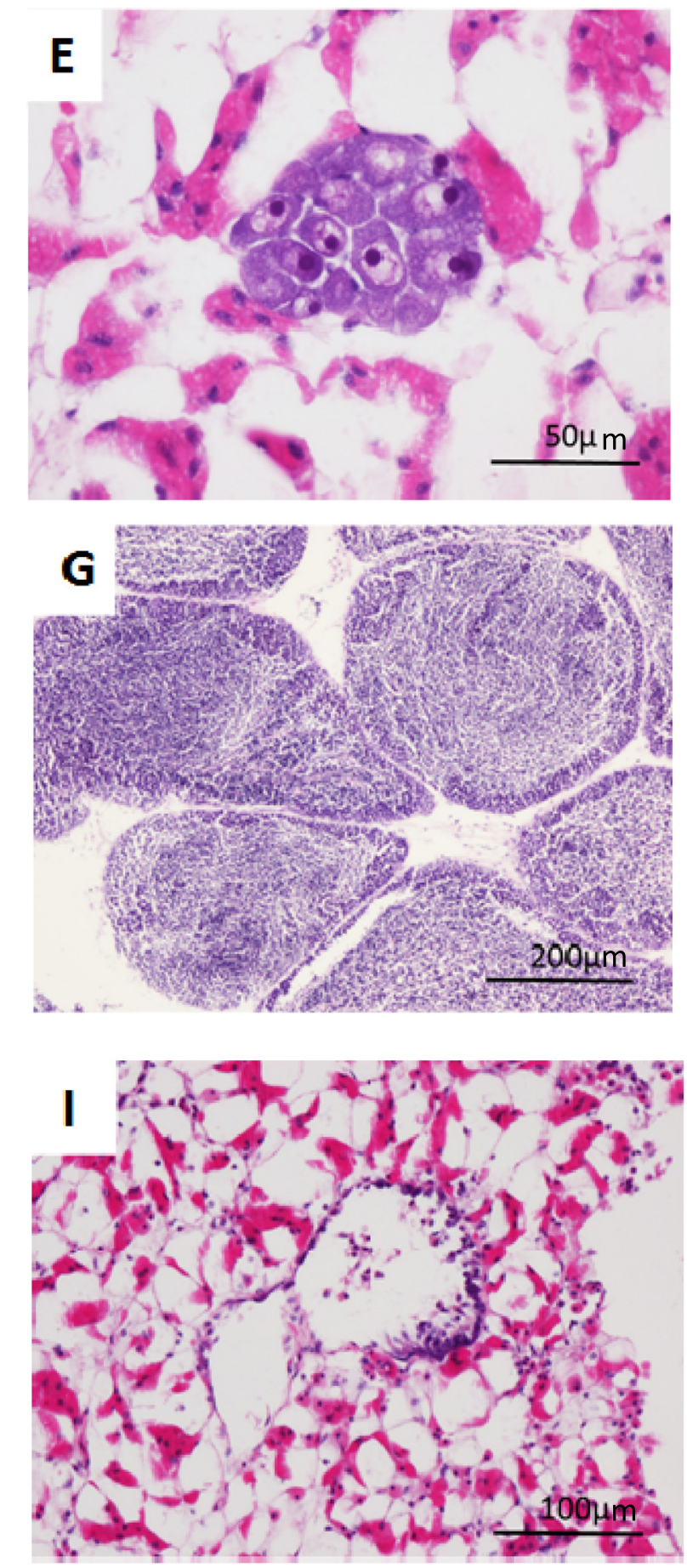


\subsection{Trace metal tissue burden}

Some of the metal tissue burdens showed significant differences among groups (Table 2). Mussels from Kiel collected in summer showed significantly higher concentrations of $\mathrm{Hg}, \mathrm{Zn}$ and $\mathrm{Mn}$ compared to the rest of the groups.

\subsection{Adipogranular cell index}

The adipogranular cell index did not show significant differences between the sampling localities but the highest value was measured in autumn and the lowest in spring (Fig. 3A).

\subsection{Gamete development}

The gamete developmental stage displayed differences regarding the season and the sampling site. In summer in Kiel half of the mussels were in a post-spawning phase (Fig. 3I) while 33\% of the analyzed mussels showed advanced gametogenesis, $11 \%$ had undifferentiated gametes (Fig. 3D), and 5\% were in an advanced gametogenic stage. Mussels collected in autumn were mostly in an early gametogenic state (90\%) and, to a lesser extent, in advanced gametogenesis (10\%). The majority of the mussels in spring were in an advanced gametogenesis state (80\%) (Fig. 3B, F), some being in the early gametogenesis phase $(10 \%)$ (Fig. 3E) or having ripe gametes (10\%) (Fig. 3G). In Tvärminne (Fig. 3C) In summer, $44 \%$ of the mussels were in an advanced gametogenic state and another $44 \%$ displayed ripe gametes, the last $11 \%$ being in the spawning phase (Fig. $3 \mathrm{H}$ ). In autumn the largest fraction of the mussels (58\%) was in an advanced gametogenic stage, 31\% displayed the spawning phase, and $10 \%$ were in early gametogenesis. In spring the majority of the mussels were in an advanced gametogenic state (95\%), and the rest exhibited early gametogenesis (5\%).

\subsection{Biochemical biomarkers}

AChE activity measured in the gills of mussels showed no statistical differences between the two localities (Fig. 4A). However, the values obtained in spring were significantly lower than those measured in summer and autumn at both sites. CAT activity in the digestive gland showed significant differences between the localities and seasons (Fig. 4B). Mussels from Kiel showed the highest activity in spring and lowest in summer. CAT activity increased again in autumn, reaching intermediate values. In Tvärminne, the highest CAT mean activity was measured in summer and the lowest in autumn, with intermediate values being recorded in the spring samples. GST activity in the digestive gland of mussels from Kiel was highest in spring, the levels being statistically significant different compared to the summer and autumn values and to those measured in mussels collected in spring in Tvärminne (Fig. 4C). The highest GST activity in the Tvärminne mussels was measured in summer, the difference being statistically significant when compared with the spring and autumn levels and with mussels collected in summer in Kiel.

LPO levels were significantly higher in both localities in autumn while mussels sampled in Tvärminne in summer showed intermediate values (Fig. 4D). There were no statistically significant differences in LPO levels between the localities.

\subsection{Cellular biomarkers}

Lipofuscin content in the digestive gland of mussels showed significant differences among the three seasons at both sampling sites (Fig. 5A). In the case of Kiel the highest values were measured in mussels collected in autumn, followed by spring and summer. In Tvärminne the highest significant lipofuscin content was observed in spring. No differences between mussels collected in summer and autumn could be observed at this site. No statistical differences regarding neutral lipid content could be noted among the sampling localities and seasons (Fig. 5B). Measurements on lysosomes in the spring samples could not be reliably performed due to the insufficient staining quality and interferences with lipofuscin-like granules. The lysosomal stability test did not show significant differences among seasons or localities (Fig. 5C). Lysosomal volume density did not show significant differences in Kiel or Tvärminne between the summer and autumn samples, although the values were significantly higher in Kiel in autumn compared to Tvärminne (Fig. 5D). The lysosomal surface/volume ratio showed a significant decrease from summer to autumn in mussels from Kiel while in samples from Tvärminne no significant differences between the seasons could be observed (Fig. 5E). In Kiel the ratio was significantly higher in autumn compared to mussels from Tvärminne. No significant differences were found in lysosomal numeric density between the seasons and localities (Fig. 5F).

\subsection{Tissue-level biomarkers and histopathology}

Volume density of basophilic cells did not show within-site seasonal variability (Fig. 6A). However, in the spring and summer samples the values measured in mussels from Kiel were significantly higher than in those from Tvärminne. The atrophy index did not show any seasonal pattern in Kiel while in Tvärminne the mussels collected in spring showed significantly lower atrophy levels compared to the summer and autumn samples (Fig. 6B). The only statistically significant differences between the localities were found in autumn when mussels from Tvärminne exhibited higher atrophy levels compared to Kiel. The connective to digestive tissue ratio (CTD) did not change significantly during the season in Kiel (Fig. 6C) but in Tvärminne the mussels had a significantly lower CTD in spring compared to summer and autumn. In spring the CTD ratio was significantly higher in Kiel compared to Tvärminne.

The pathologies found were related to inflammatory responses (haemocytic and brown cell infiltrations), granulocytomas and atresia of oocytes. The parasites found where digenean and MPX intracellular ciliates (Table 3). In mussels from Tvärminne haemocytic infiltrations were found in spring (85\% of individuals), summer (70\%) and autumn (80\%). The highest prevalence of haemocytic infiltrations in Kiel was detected in summer (55\%). No statistically significant differences between the sampling localities and seasons could be observed. The prevalence of brown cell infiltrations in the digestive tissue was significantly higher in mussels from Tvärminne in spring (70\%) compared to all the other samples where the prevalence was low (0-25\%). Brown cell infiltration prevalence in the gonad tissue was significantly higher in the Tvärminne mussels (80\%) in summer while the other two seasons presented lower prevalences (spring $45 \%$, autumn 0\%). In Kiel the prevalences were overall very low (spring $0 \%$, summer $10 \%$ and autumn $5 \%$ ).

Granulocytomas were observed only in Tvärminne spring samples (20\%). The prevalence of oocyte atresia in Kiel was the highest in spring (90\%), and decreased in summer (13\%) and autumn (7\%). Mussels from Tvärminne showed the highest prevalence in spring (100\%) while in summer (87\%) and autumn (61\%) the values were lower although differences were not statistically significant when comparing the localities and seasons.

Parasitic burden was overall low at both study sites. Digenean parasites were slightly more common in Kiel (spring 10\%, summer 14\% and autumn 5\%) than in Tvärminne (spring 5\%, summer and autumn 0\%) (Fig. 6D). MPX ciliate infection intensities were always below 50

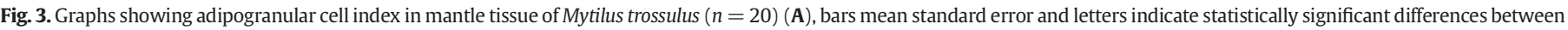

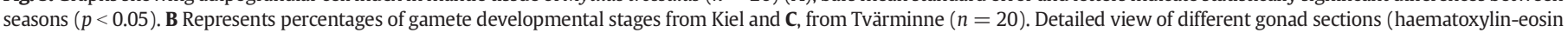

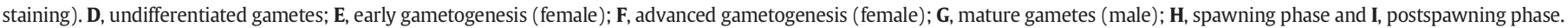


individuals per tissue section (Fig. 6E). The MPX prevalence was low in Kiel (spring and summer 5\%, autumn 10\%), while in Tvärminne they were only found in spring with a significantly higher prevalence (26\%). Rickettsia-like organisms (RLO) in the digestive gland were not found at all in Kiel while their prevalence in Tvärminne was very low (spring 5\%, summer 10\% and autumn 5\%) and seasonal differences were not significant (Fig. 6F). The highest number of RLO in a single section was 14.

\subsection{IBR}

The biomarkers selected for the IBR were the following: CAT activity (oxidative stress defence) and LPO levels (oxidative damage) in the digestive gland at biochemical level; $\mathrm{Vv}_{\mathrm{NL}}$ in digestive cells at subcellular level; $\mathrm{Vv}_{\text {BAS }}$ at cellular level and CTD ratio as a tissue level biomarker. These biomarkers were chosen because they represent different biological organization levels and functions, thus allowing for a summarized holistic view of the biological responses measured in this study. The six profiles depicted by the five biological response parameters exhibited seasonal and temporal variability as illustrated in Star plots (Fig. 7). CAT, $\mathrm{Vv}_{\mathrm{BAS}}$ and CTD showed the highest response in the Kiel mussels sampled in spring, resulting in the highest IBR/n value, statistically differing from the others. Overall, the lowest response levels in the selected biomarkers were measured in Tvärminne in spring, resulting in the IBR/n value showing the significantly lowest value. Mussels sampled in summer at both localities show overall intermediate levels of response. Mussels collected in autumn from Kiel showed high $\mathrm{Vv}_{\mathrm{NL}}$ and high CTD as in mussels from spring. The IBR/n value in Kiel autumn is higher than the value from Kiel summer and Tvärminne autumn, although the differences are not statistically significant. Mussels from Tvärminne sampled in autumn exhibited the highest LPO response while the rest of the biomarkers show intermediate responses and the $\mathrm{IBR} / \mathrm{n}$ value is similar to the mussels collected in summer.

\section{Discussion}

The Baltic Sea exhibits large temporal and spatial variability in environmental factors (i.e., temperature, salinity) that may affect biomarker responses. Hence, the measurement of different physicochemical and ecological variables by remote sensing (Frouin et al., 1989; Stramski et al., 2008; Hu et al., 2012; Kilpatrick et al., 2015) can provide a logistical advantage in gathering information of ecological variables without the necessity of additional samplings and/or measurements. However, it has to be considered that satellite data can only represent regional features of the studied variables and will always be affected by problems due to atmospheric transmission of radiation (e.g., missing data due to clouds). As such, in-situ data naturally always represent measurements with a better match of scales than satellite data, particularly in regions very close to the coast.

Sea surface temperature is a critical parameter for mussels in the shallow Baltic Sea as it is affected by upwelling processes and is consequently related with vertical mixing of the water column and the subsequent mobilization of nutrients which determine phytoplankton dynamics (Wasmund et al., 2008). In this study, anomalies were not found regarding SST when comparing the sampling years with the yearly seasonal cycle, although the temperature trends are different in both localities. Tvärminne exhibits longer periods with lower temperatures, and the period of high summer temperatures is shorter than in Kiel. When comparing the sites within the Baltic Sea especially along the south-north axis, seasonal trends need to be taken carefully into account because the mussels sampled at a given date might be under the influence of different environmental conditions.

Similar trends in SST can be seen regarding chl- $a$ and POC concentrations. In Kiel, the mussels were sampled during the second peak of the spring phytoplankton bloom and POC, and to a smaller extent some time before the autumn mussel collection. During the summer sampling in Kiel the food supply was at its lowest levels. In Tvärminne, chl- $a$ and POC concentrations were at high levels when the mussels were collected in spring, coinciding with the first bloom of phytoplankton and organic carbon of the year. Afterwards, a stable food supply was maintained until summer. In autumn mussels from Tvärminne were presumably in a relatively good nutritive condition rendered by unusual high food supply in spring months. This could indicate that the massive cyanobacterial summer bloom that regularly occurs in the Gulf of Finland a few weeks between late June-early August (often consisting of almost monocultures of the toxic Nodularia spumigena, Raateoja et al., 2011) did not render a significant physiological stress to the mussels while not providing them a good food source neither.

Total PAH tissue burden was overall low and all the different compounds above the detection limit were in every case below to what is considered good environmental status (GES) in the Baltic Sea (HELCOM, 2018). Although the sum of the 15 PAHs in mussels collected in autumn from Kiel was significantly higher than in the rest of the samples it cannot be considered as a site of concern compared to previous data from the Baltic Sea (e.g., Turja et al., 2015). The concentrations of trace metals in soft tissues were also low. The three metals (cadmium, lead and mercury) that are considered priority substances in the Baltic Sea were below or slightly above the GES threshold values (HELCOM, 2017). Conclusively, the overall low levels of pollutants at the sampling stations suggest that the recorded variability in biomarkers was not greatly impacted by pollutants but due to the other factors discussed here.

In the present study, the highest ADG cell density in both localities was found in autumn when the spawning had already occurred, which is coherent with the above. The fact that higher levels of ADG cells were measured in autumn indicates the necessity of mussels to accumulate reserve energy for the winter low-nutrition period, which in the northern Baltic Sea lasts longer than in the south.

Differences in the gametogenic stage of mussels between the localities might affect the biomarkers employed in the assessment of their health status (Cuevas et al., 2015). In Kiel, the spring bloom can occur between mid February and beginning of April (Wasmund et al., 2008), which is coherent with the spawning period detected in this work (probably March or beginning of April), while in Tvärminne the mussels spawned in summer and autumn. The first spawning period is apparently connected with the intensive spring bloom while the second one to a lesser autumn bloom. It is obvious that the physiological condition of mussels sampled at the same time at the two sites can be quite different. Therefore, it can be concluded that the timing of the phytoplankton blooms vary in different regions of the Baltic Sea and regulate the onset of spawning; Thus, when assessing the health status of mussels using biomarkers, local conditions should be taken carefully into account to avoid misinterpretations.

The measured biochemical biomarkers showed different seasonal patterns. The only significant difference was observed in AChE activity in gills between spring and the other two sampling seasons at both sampling localities. It has been previously described that temperature is the main natural factor influencing AChE activity (Bocquené and Galgani, 1998; Leiniö and Lehtonen, 2005) and, accordingly, an increase in AChE activity in summer was related to the increase in water temperature. CAT and GST activities in the digestive gland seemed to be conditioned by the food supplied during the blooms and by the reproductive cycle of mussels, since the activity peaks were coincident with the spawning seasons (spring in Kiel and summer in Tvärminne). Although CAT and GST activity levels were not very high in mussels from Tvärminne in autumn, even though spawning had occurred, the low activity could be associated to the relatively lower digestive activity. It has been suggested that the variability in antioxidant enzyme activity is presumably linked with a changing metabolic status depending on factors such as temperature, gonad ripening and food availability (Regoli, 1998; Vidal et al., 2002). Leiniö and Lehtonen (2005), in agreement with the present results, also described and increase in CAT and 

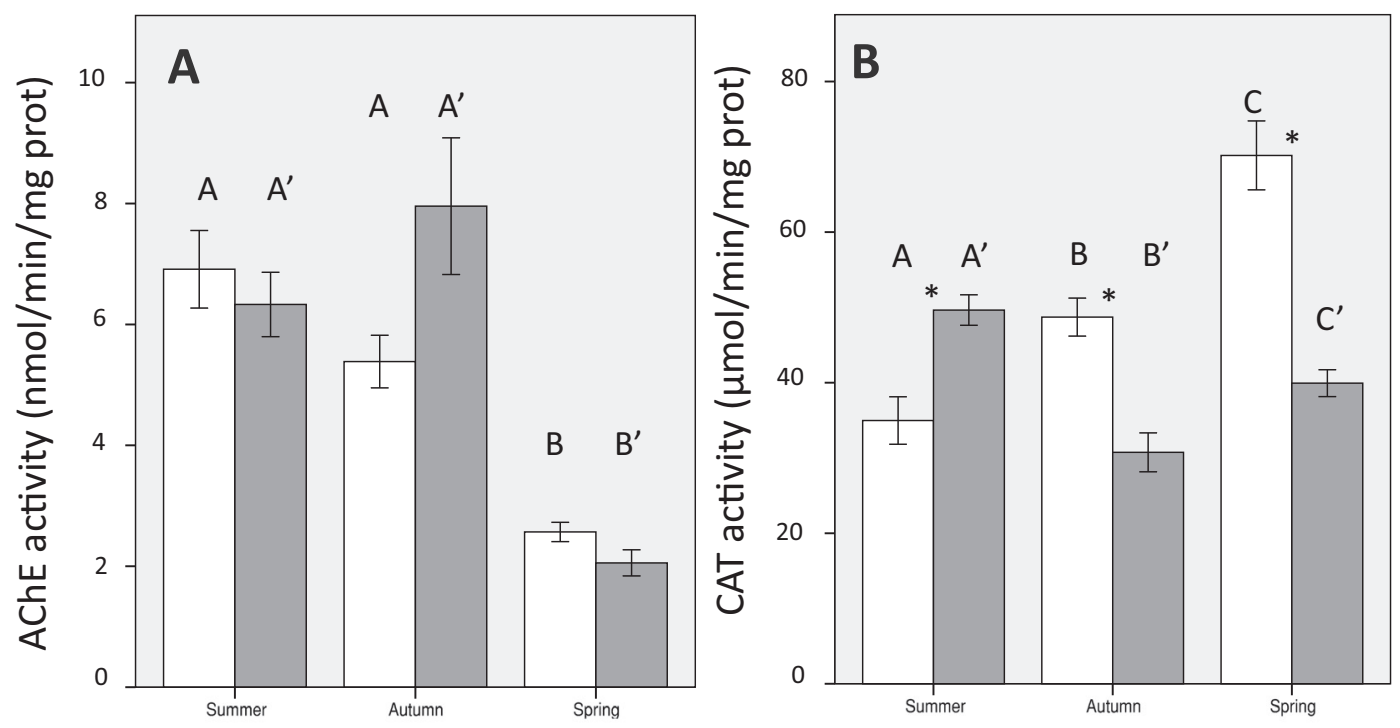

$\square \mathrm{KIEL}$
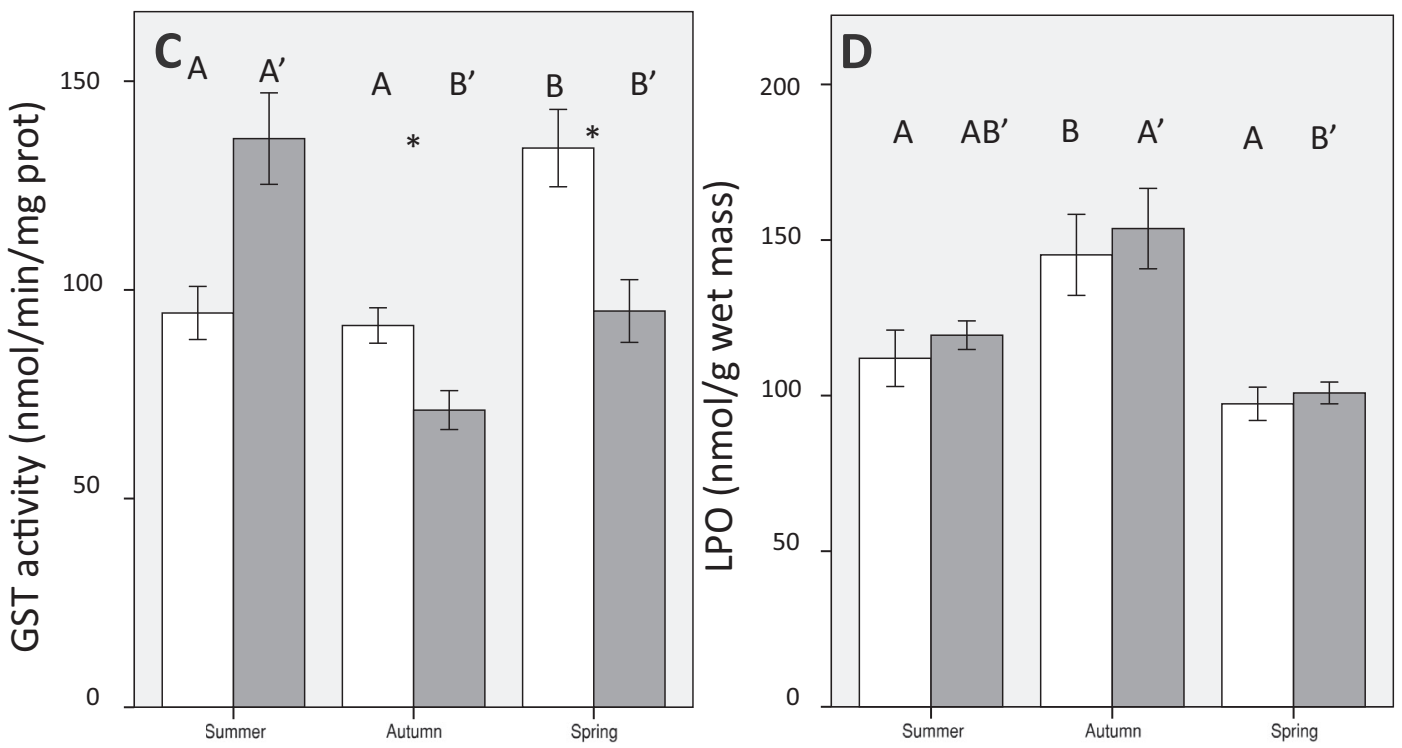

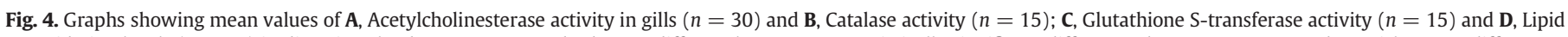

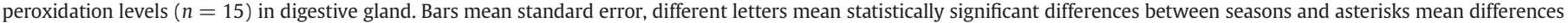
between sampling sites in the same season $(p<0.05)$.

GST activities in the digestive gland of mussels from the Baltic Sea related to the factors previously stated, except temperature. Moreover, previous studies have described the effect of environmental factors in the responsiveness of these biomarkers also in the southern Baltic Sea (Kopecka et al., 2006), which is coherent with the variability observed in the present work.

In both locations, the levels of LPO were higher in autumn compared to the two other sampling times. Previous studies have shown that cellular membranes rich in polyunsaturated lipids are susceptible to react with free radicals (Shaw et al., 2004); thus, an adaptation of the cellular membrane in terms of increased fluidity (more polyunsaturated fatty acids) to cold temperatures in winter might explain the higher susceptibility to oxidative damage measured in mussels collected in autumn. Changes in the cellular membrane lipids as an adaptation to cold have been previously described in other marine organisms from the Baltic Sea such as amphipods (Lahdes et al., 2010); however, this topic deserves further investigations. In conclusion, biochemical biomarkers presented high seasonal variability influenced by environmental factors and it is therefore critical to gather knowledge about reference levels in different seasons and localities when these biomarkers are used to assess biological effects caused by pollutants.
The high volume density of lipofuscins in mussels collected in spring from Tvärminne is likely caused by the long period of food deficiency during the winter due to low primary production. Nutritional stress in mussels inhabiting areas under ice cover in winter has been previously described (Hatcher et al., 1997) and, in addition, the higher LPO levels measured in autumn may indicate that the strategy necessary for mussels to survive the harsh winter conditions in Tvärminne make them more susceptible to oxidative damage during this period. Moreover, a high digestive activity after ice melting during the first spring phytoplankton bloom may indicate the enhanced presence of lipofuscins inside the digestive cells. The high lipofuscin accumulation in mussels sampled in autumn in Kiel is concordant with the lysosomal structural changes measured. Furthermore, the elevated LPO levels in autumn could be the reason for the high lipofuscin accumulation levels at this site. Although similar lipid peroxidation levels were measured in autumn also in Tvärminne, lipofuscin accumulation and lysosomal structural changes did not follow the same trend. Since only low levels of PAHs were measured in mussel soft tissues, the observed changes in neutral lipid accumulation can be expected to be related to physiological and/or ecological changes. Lipid content in the digestive gland is not as directly related to the reproductive cycle as that in the mantle 

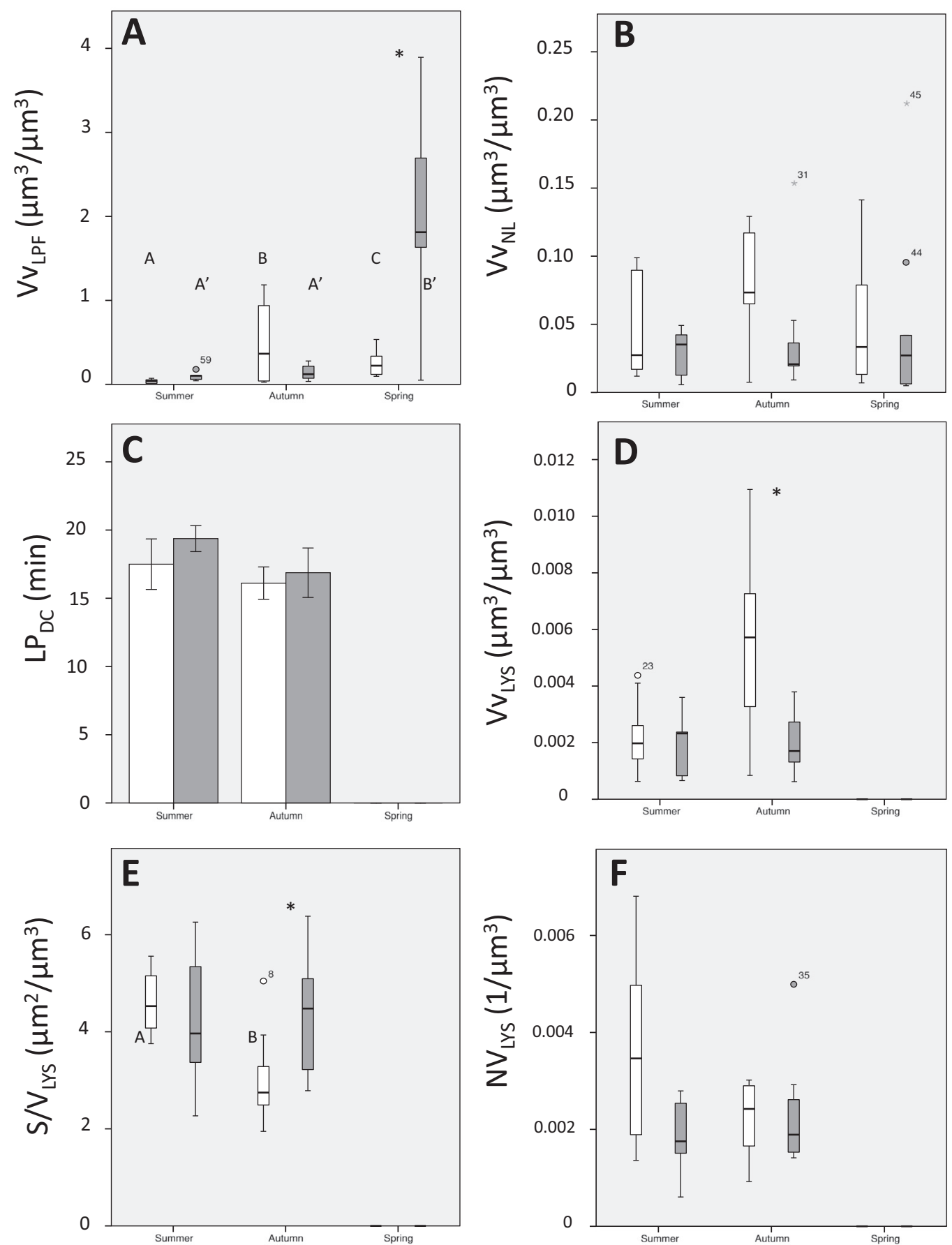

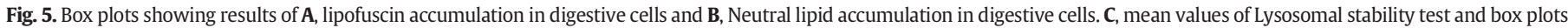

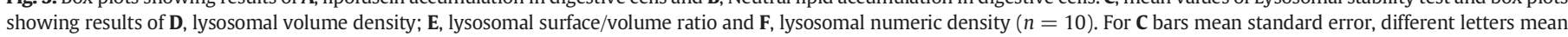
statistically significant differences between seasons and asterisks mean differences between sampling sites in the same season $(p<0.05)$.

tissue (Moukrim et al., 2008). Thus, according to the results of the present study, neutral lipid content in the digestive gland is a potentially valuable biomarker of exposure to organic pollutants as it did not show significant variability throughout the different seasons at these relatively low-impact sites.

Unfortunately, lysosomal alterations could not be reliably measured in both localities in spring. In the case of lysosomal structural changes measurements, mussels from Kiel presented unusual dark spots in the digestive cells after the $\beta$ glucuronidase staining, making it impossible to perform a correct measurement of lysosomal populations. Mussels from Tvärminne presented widespread spots of granular shape in the digestive cells, and the stereological measurements were therefore unreliable. The failure to measure these parameters in mussels from Tvärminne is probably related to the high intracellular lipofuscin and/ or algal intracellular content which could interfere the histochemical staining of the enzymatic activity and cause misleading measurements (Mújica et al., 2015a). In the case of mussels from Kiel, the reasons for the dark spots are unclear. Results of the lysosomal stability test from the samples in which it was measurable were similar in both seasons and sampling sites, and were close to the values in mussels from the Cantabrian coast described as non-stressed (>20 min) (Marigómez et al., 2006). Regarding lysosomal structural changes, the only significant differences were found in mussels sampled in autumn from Kiel when the volume density was higher than in mussels from Tvärminne 

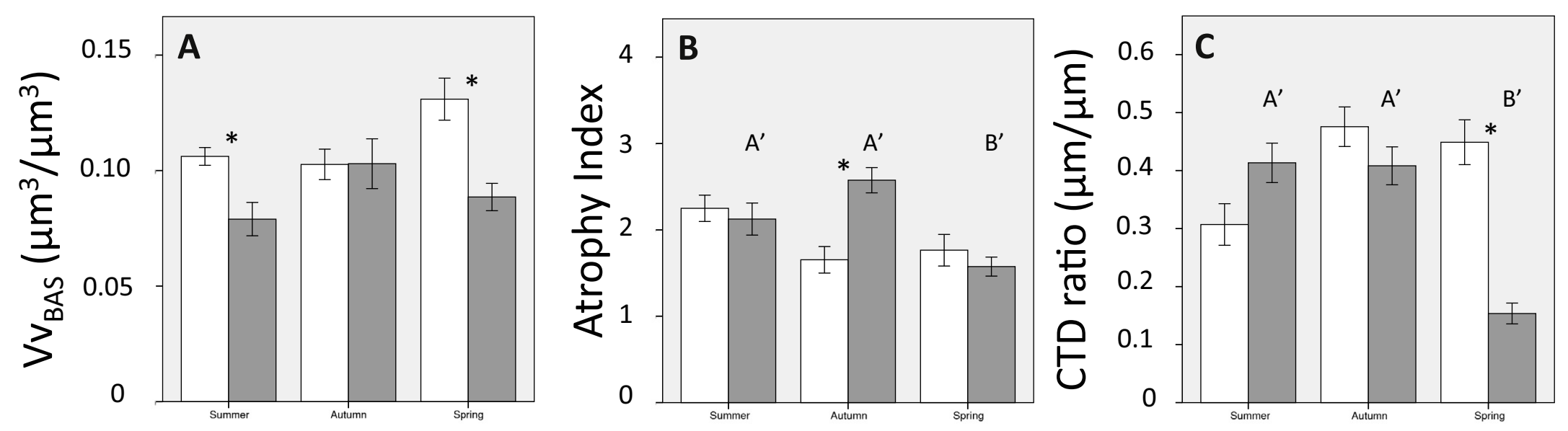

\section{$\square$ KIEL} $\square T V A ̈ R$
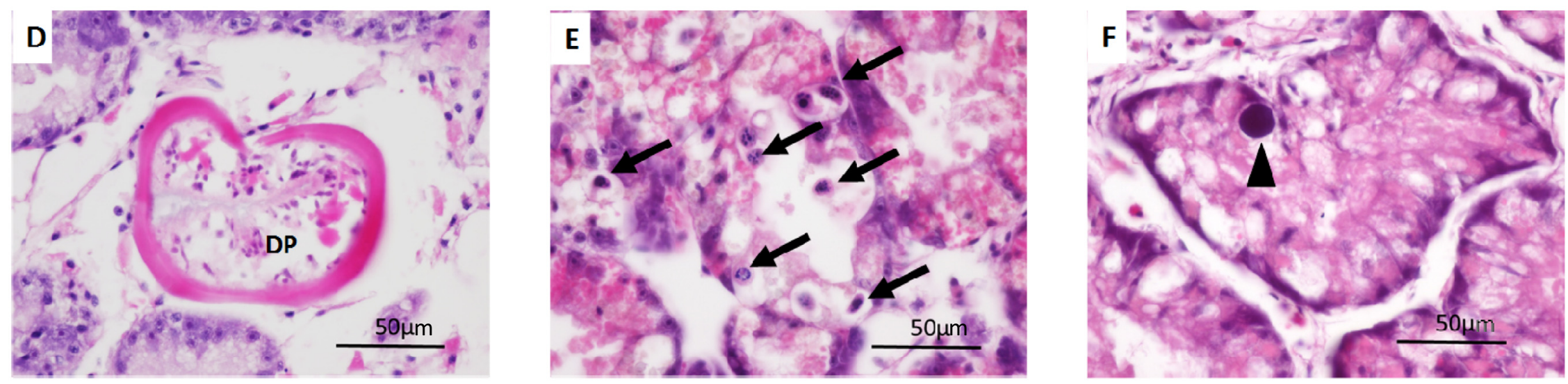

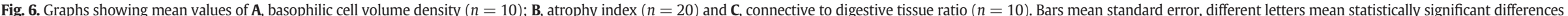

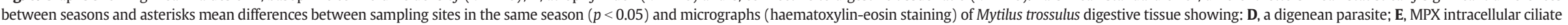
and F, Rickettsia like organism. DP, digenean parasite; Arrows, MPX ciliates and arrowheads Rickettsia-like organism. 
Table 3

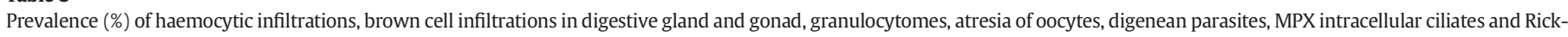

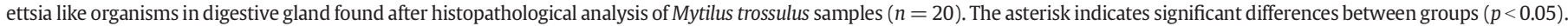

\begin{tabular}{|c|c|c|c|c|c|c|}
\hline & Kiel summer & Kiel autumn & Kiel spring & Tvärminne summer & Tvärminne autumn & Tvärminne spring \\
\hline Haemocytic inf. & 55 & 25 & 10 & 70 & 80 & 85 \\
\hline Brown Cells (DG) & 25 & 15 & 5 & 0 & 0 & $70^{*}$ \\
\hline Brown Cells (GO) & 10 & 5 & 0 & $80^{*}$ & 0 & 45 \\
\hline Granulocytoma & 0 & 0 & 0 & 0 & 0 & $20^{*}$ \\
\hline Atresia & 13.33 & 6.67 & 90 & 87.5 & 61.54 & 100 \\
\hline Digenean par. & 14.29 & 5 & 10 & 0 & 0 & 5 \\
\hline MPX & 5 & 10 & 5 & 0 & 0 & $26.32^{*}$ \\
\hline RLO (DG) & 0 & 0 & 0 & 10 & 5 & 5 \\
\hline
\end{tabular}

during the same season, and the surface/volume ratio was smaller than in mussels from Kiel in summer and mussels from Tvärminne during the same seasons. Lysosomal enlargement can happen when mussels are exposed to different pollutants (Marigómez et al., 2005) or when some natural factors change (Izagirre et al., 2008). As discussed, the possible effects of pollutants are probably very limited due to the low tissue burden of metals and PAHs used as a proxy of local chemical pollution. The lysosomal enlargement described in mussels collected from Kiel in autumn is concordant with other biomarker responses such as lipid peroxidation and lipofuscin accumulation.
Tissue level biomarkers showed different trends among them. For instance, $\mathrm{Vv}_{\mathrm{BAS}}$ did not show seasonal variability at any of the sites although significant differences were found between the localities in spring and summer. The highest $\mathrm{Vv}_{\mathrm{BAS}}$ in the present work suggest slight stress compared to the baseline values defined in mussels from the Cantabrian Sea $\left(0.1 \mu^{3} / \mu \mathrm{m}^{3}\right)$ (Marigómez et al., 2006; Garmendia et al., 2010). The high $\mathrm{Vv}_{\text {BaS }}$ value measured in mussels from Kiel was recorded immediately before the spawning period and could be explained as transient stress, but this does not explain why the summer value in Kiel is still higher than in Tvärminne where mussels are
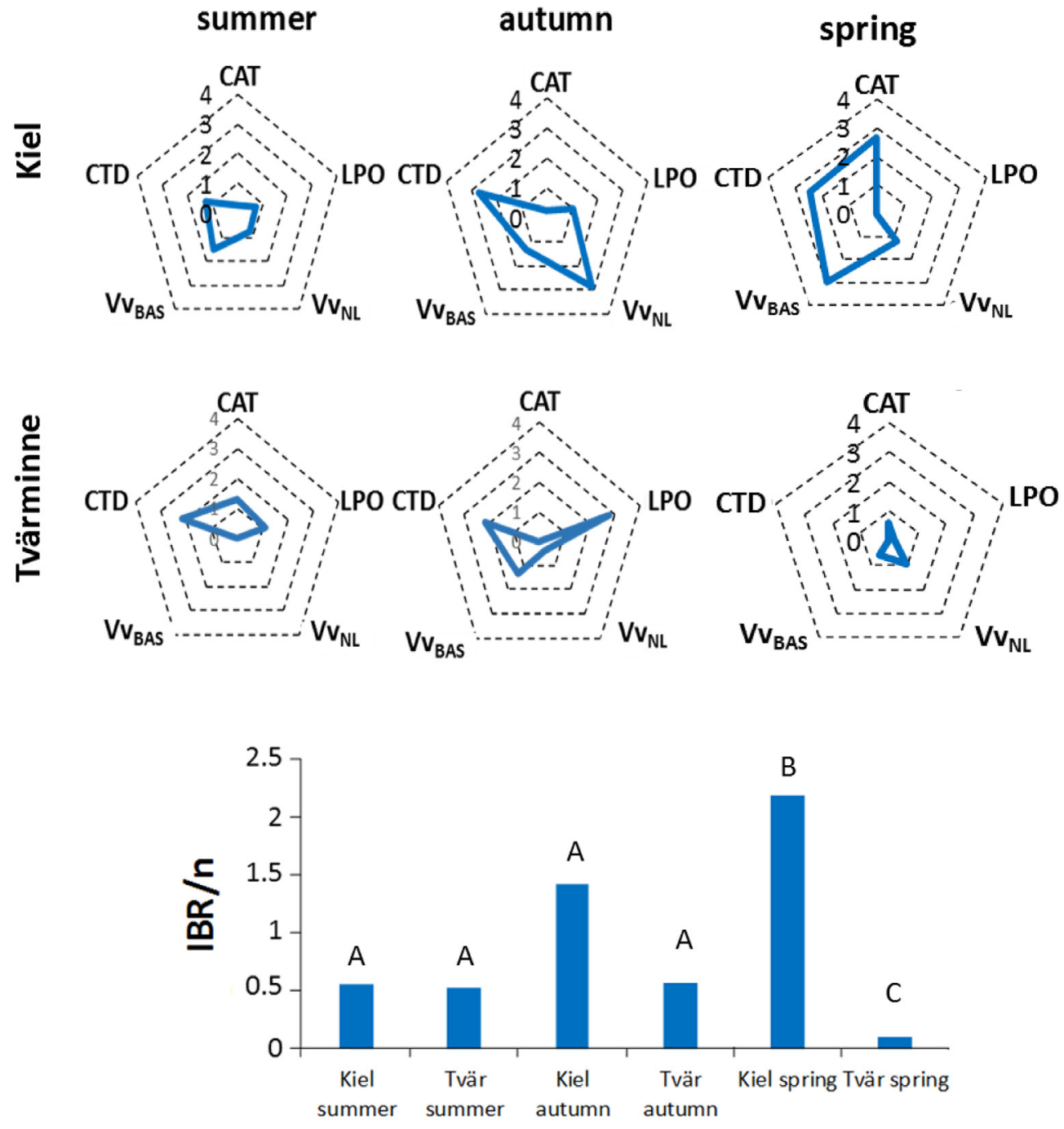

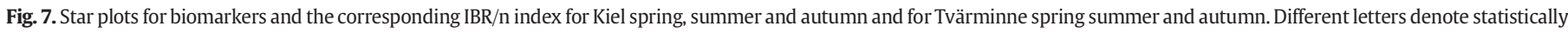

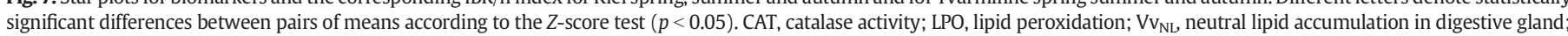
$\mathrm{Vv}_{\mathrm{BAS}}$, volume density of basophilic cells; CTD, connective to digestive tissue ratio. 
spawning at that time. Apparently, the natural range of $\mathrm{Vv}_{\mathrm{BAS}}$ in Kiel mussels exhibits higher baseline values than that in Tvärminne and this must be taken into account when assessing the impacts of chemical stressors.

No marked seasonal differences in CTD were found in Kiel but in Tvärminne significantly higher values were recorded in summer and autumn during the local spawning periods. In molluscs, a high CTD value indicates a loss of integrity of the digestive gland, potentially caused by a chemical stressor or by poor nutritive status (Mújica et al., 2015b; Benito et al., 2017). After the breaking of ice in spring and the subsequent intensive algal bloom the mussels need to assimilate the maximum amount of food in order to replenish their energy reserves, as described in mussels from the North Atlantic (Hatcher et al., 1997). Conclusively, a rapid maturation of gonads after these events requires high energetic investments that could explain the higher digestive alveoli atrophy and CTD values observed during the spawning seasons in boreal environments such as the Gulf of Finland. The fact that mussels in Kiel seem to be less affected by the reproductive cycle regarding epithelial thinning and CTD ratio is likely related to the more stable food availability in the southwestern Baltic Sea, and consequently, the energetic trade-off related to reproductive investment is lower than in Tvärminne (Larsson et al., 2018).

Haemocytic infiltration (immune response) was common in mussels from Tvärminne during all the studied seasons and to a lesser extent in mussels from Kiel in summer. Previous studies have linked haemocytic infiltration with environmental and physiological factors including starvation, spawning stress and parasitism (Couch, 1985; Garmendia et al., 2011), also in the Gulf of Finland (Sunila, 1987). Accordingly, the high prevalence of haemocytic infiltration in mussels from Tvärminne could be primarily related to the low salinity in the area and to the unstable food supply as previously reported (Malagoli et al., 2007; Bussell et al., 2008; Höher et al., 2012). Even when food is more abundant (high Chl- $a$ and POC) the spawning effort causes marked stress, as evidenced by different biomarker responses, which could at least partly explain the high levels of haemocytic infiltration. In the case of mussels collected in spring from Tvärminne, the high prevalence is possibly related to the long winter starvation period. In mussels from Kiel, the higher prevalence is possibly associated with the slightly higher digenean parasite prevalence and to the lower food availability after the spring bloom and spawning. Brown cell infiltration in the digestive gland was observed in the digestive tract epithelium, where melanized haemocytes were observed crossing the epithelium by diapedesis. The highest frequency of diapedesis occurred in mussels sampled in spring in Tvärminne and this could be a possible mechanism to eliminate lipofuscin granules/microalgae (Galimany et al., 2008). Varying frequencies of diapedesis have been observed also previously in mussels from the Northern Baltic Sea (Lehtonen, 1989). The presence of brown cells in gonad follicles and atresia of oocytes are indicators of ongoing autolysis and resorption processes during gametogenesis, and can be induced when environmental conditions become unfavorable for spawning after gamete maturation (Newell, 1989; Suárez Alonso et al., 2005; Smolarz et al., 2017). Brown cell infiltrations were at the highest level in mussels sampled in summer in Tvärminne, followed by those collected in spring at the same site. High brown cell infiltration and oocyte atresia prevalence might both indicate a demanding energetic strategy necessary for Tvärminne mussels to survive. Further, atresia declines from spring to autumn and the spawning occurs in summer and autumn similar to mussels in Kiel and is probably related to the lower amount of mature gametes after the spawning periods, which is potentially caused by gamete reabsorption.

Granulocytomas are inflammatory responses resulting in vascular occlusions (Lowe and Moore, 1979) that have been linked to chronic pollution and the presence of metacercarian parasites (Garmendia et al., 2011). In this study, granulocytomas were found only in Tvärminne mussels sampled in spring (20\%). This pathology is unlikely to be caused by the very low pollutant concentrations measured in tissues or parasitic burden (only high for intracellular MPX ciliates). Other reason, as pointed out by Rasmussen (1986), is the relationship between granulocytomas formed by granular leucocytes and viral infections. Accordingly, granulocytomas were found in spring in Tvärminne where the immune system was depressed, and a subsequent greater susceptibility to infections is expected after the winter starvation period. Butt et al. (2007) demonstrated that starvation compromises immunological activity in Sydney rock oysters (Saccostrea glomerata). Nevertheless, only one granulocytoma of small size was found per individual in the present study and these lesions are therefore not likely to be highly compromising for the individuals inhabiting relatively clean sampling locations.

Finally, the IBR/n index calculated from selected biomarkers corresponded well with the spawning seasons in both locations although the responses measured were different. In spring, the IBR/n value was the highest for mussels from Kiel, suggesting a concomitant stress situation to the spawning. Oppositely, the lowest IBR/n value was observed for mussels collected in spring from Tvärminne, when spawning had yet to take place. The two periods during which the spawning occurred in Tvärminne and the two periods after the spawning in Kiel showed similar integrated stress levels.

\section{Conclusions}

When recording varying biomarker response trends in mussels inhabiting different localities it is conceivable that the populations might be under the influence of different environmental conditions. In this study, maturation of gametes and spawning are of overwhelming importance since they influence biochemical responses (catalase and GST), and histological (CTD and atrophy) and histopathological alterations. Since gamete development is clearly influenced by food supply the importance of a detailed characterization of physico-chemical conditions (here assessed by satellite data) of the studied locations in field studies is evident. More specifically, the sub-regions of the Baltic Sea are characterised by oceanographic and climatic features that are much more variable in this temperate/boreal/subarctic gradient compared to temperate areas. In mussels from the Baltic Sea, the increase of ADG levels observed in autumn are probably related to the necessity of storing reserve material for winter and consequently higher probability of LPO, lipofuscin accumulation and lysosomal enlargement. In Tvärminne, the very long winter period (including ice coverage) influences the seasonal strategy of mussels focusing on somatic recovery in spring (high feeding activity inducing high lipofuscin content and low atrophy index and CTD ratio). As neutral lipid accumulation was not significantly affected by seasonal fluctuations in environmental factors, this biomarker is well recommendable for the monitoring of the effects of organic pollutants in Baltic Sea mussels. For the rest of the biomarkers studied here it is highly important to recognize the effects of season as well as the various and fluctuating environmental factors affecting the natural baseline levels in different parts of the Baltic Sea. Characterization of the ecological variables and physico-chemical conditions at each site is crucial to perform a reliable assessment of the effects of pollution in the Baltic Sea.

\section{Acknowledgements}

This work was funded by EU GRACE Project (Grant Agreement Number 679266), grant CGL2016-76561-R (MINECO/ERDF, UE). Additional funding was received from the University of the Basque Country (UPV/EHU, UFI 11/37 fellowship, GIU 17/002) and Basque Government (IT810-13). Satellite data were provided by NASA Goddard Space Flight Center, Ocean Ecology Laboratory, Ocean Biology Processing Group; 2018, Ocean Color Data, NASA OB.DAAC. Accessed on 2018/10/29. Dr. Matthias Brenner (Alfred Wegener Institute for Polar and Marine Research, Bremerhaven, Germany) is gratefully acknowledged for the sampling and preparation of mussels collected from the German coast. 


\section{References}

Azpeitia, K., Ortiz-Zarragoitia, M., Revilla, M., Mendiola, D., 2017. Variability of the reproductive cycle in estuarine and coastal populations of the mussel Mytilus galloprovincialis Lmk. From the SE Bay of Biscay (Basque Country). International Aquatic Research 9 (4), 329-350.

Beliaeff, B., Burgeot, T., 2002. Integrated biomarker response: a useful tool for ecological. Environ. Toxicol. Chem. 21, 1316-1322.

Benito, D., Niederwanger, M., Izagirre, U., Dallinger, R., Soto, M., 2017. Successive onset of molecular, cellular and tissue-specific responses in midgut gland of Littorina littorea exposed to sub-lethal cadmium concentrations. Int. J. Mol. Sci. 18, 1-26.

Beyer, J., Green, N.W., Brooks, S., Allan, I.J., Ruus, A., Gomes, T., Bråte, I.L.N., Schøyen, M., 2017. Mar. Environ. Res. 130, 338-365.

Bignell, J.P., Dodge, M.J., Feist, S.W., Lyons, B., Martin, P.D., Taylor, N.G.H., Stone, D. Travalent, L., Stentiford, G.D., 2008. Mussel histopathology, effects of season, disease and species. Aquat. Biol. 2, 1-15.

Bocquené, G., Galgani, F., 1998. Biological effects of contaminants: cholinesterase inhibition by organophosphate and carbamate compounds. ICES Tech. Mar. Environ. Sci $22,12$.

Bradford, M., 1976. A rapid and sensitive method for the quantitation of microgram quantities of protein utilizing the principle of protein-dye binding. Anal. Biochem. 72 , 248-254.

Brenner, M., Broeg, K., Frickenhaus, S., Buck, B.H., Koehler, A., 2014. Multi-biomarker approach using the blue mussel (Mytilus edulis L.) to assess the quality of marine environments: season and habitat-related impacts. Mar. Environ. Res. 95, 13-27.

Broeg, K., Lehtonen, K.K., 2006. Indices for the assessment of environmental pollution of the Baltic Sea coasts: integrated assessment of a multi-biomarker approach. Mar. Pollut. Bull. 53, 508-522.

Bussell, J.A., Gidman, E.A., Causton, D.R., Gwynn-Jones, D., Malham, S.K., Jones, M.L.M., Reynolds, B., Seed, R., 2008. Changes in the immune response and metabolic fingerprint of the mussel, Mytilus edulis (Linnaeus) in response to lowered salinity and physical stress. J. Exp. Mar. Biol. Ecol. 158 (1), 78-85.

Butt, D., Aladaileh, S., O'Connor, W.A., Raftos, D.A., 2007. Effect of starvation on biological factors related to immunological defence in the Sydney rock oyster (Saccostrea glomerata). Aquaculture 264 (1-4), 82-91.

Cajaraville, M.P., Bebianno, M.J., Blasco, J., Porte, C., Sarasquete, C., Viarengo, A., 2000. The use of biomarkers to assess the impact of pollution in coastal environments of the Iberian Peninsula: a practical approach. Sci. Total Environ. 247 (2-3), 295-311.

Cancio, I., Ibabe, A., Cajaraville, M.P., 1999. Seasonal variation of peroxisomal enzyme activities and peroxisomal structure in mussels Mytilus galloprovincialis and its relationship with the lipid content. Comp. Biochem. Physiol. 123C, 135-144.

Cheung, C.C.C., Zheng, G.J., Li, A.M.Y., Richardson, B.J., Lam, P.K.S., 2001. Relationships between tissue concentrations of polycyclic aromatic hydrocarbons and antioxidative responses of marine mussels, Perna viridis. Aquat. Toxicol. 52, 189-203.

Claiborne, A., 1985. Catalase activity. In: Greenwald, R.A. (Ed.), Handbook of Methods for Oxygen Radical Research. CRC Press, Boca Raton, pp. 283-284.

Couch, J., 1985. Prospective study of infectious and non-infectious diseases in oysters and fishes in three Gulf of Mexico estuaries. Dis. Aquat. Org. 1, 59-82.

Cuevas, N., Zorita, I., Costa, P.M., Franco, J., Larreta, J., 2015. Development of histopathological indices in the digestive gland and gonad of mussels: integration with contamination levels and effects of confounding factors. Aquat. Toxicol. 162, 152-164.

Culling, C.F.A., 1974. Handbook of Histopathological and Histochemical Techniques. 3rd edn. Butterworths, London, p. 367.

Danton, E., Kiymoto, M., Komaru, A., Wada, K.T., Awaii, M., Mathieu, M., 1996. Comparative analysis of storage tissue and insulin-like neurosecretion in diploid an triploid mussels Mytilus galloprovincialis Lmk. In relation to their gametogenesis cycle. Invertebr. Reprod. Dev. 29, 37-46.

Etxeberria, M., Sastre, I., Cajaraville, M.P., Marigómez, I., 1994. Digestive lysosome enlargement induced by experimental exposure to metals ( $\mathrm{Cu}, \mathrm{Cd}$ and $\mathrm{Zn}$ ) in mussels collected from a zinc-polluted site. Arch. Environ. Contam. Toxicol. 27 (3), 338-345.

Frouin, R., Ligner, D.W., Gautier, C., 1989. A simple analytical formula to compute clear sky total and photosynthetically available solar irradiance at the ocean surface. J. Geophys. Res. 94, 9731-9742.

Galimany, E., Sunila, I., Hégaret, H., Ramón, M., Wikfors, G.H., 2008. Experimental exposure of the blue mussel (Mytilus edulis, L.) to the toxic dinoflagellate Alexandrium fundyense: histopathology, immune responses and recovery. Harmful Algae 7 (5), 702-711.

Garmendia, L., Soto, M., Cajaraville, M.P., Marigómez, I., 2010. Seasonality in cell and tissue-level biomarkers in Mytilus galloprovincialis: relevance for long-term pollution monitoring. Aquat. Biol. 9 (3), 203-219.

Garmendia, L., Soto, M., Vicario, U., Kim, Y., Cajaraville, M.P., Marigómez, I., 2011. Application of a battery of biomarkers in mussel digestive gland to assess long-term effects of the Prestige oil spill in Galicia and Bay of Biscay: tissue-level biomarkers and histopathology. J. Environ. Monit. 13, 915-932.

Habig, W.H., Pabst, M.J., Jakoby, W.B., 1974. Glutathione S-transferases - first enzymatic step in mercapturic acid formation. J. Biol. Chem. 249, 7130-7139.

Hatcher, A., Grant, J., Schofield, B., 1997. Seasonal changes in the metabolism of cultured mussels (Mytilus edulis l.) from a Nova Scotian inlet: the effects of winter ice cover and nutritive stress. J. Exp. Mar. Biol. Ecol. 217, 63-78.

HELCOM, 2017. Metals (lead, cadmium and mercury). HELCOM Core Indicator Report. 2343-2543 (32pp)

HELCOM, 2018. Core Indication Report. Polyaromatic Hydrocarbons (PAHs) and their Metabolites (ISSN 2343-2543. 17pp).

Höher, N., Köhler, A., Strand, J., Broeg, K., 2012. Effects of various pollutant mixtures on immune responses of the blue mussel (Mytilus edulis) collected at a salinity gradient in Danish coastal waters. Mar. Environ. Res. 75, 35-44.
Honjo, S., Manganini, S.J., Krishfield, R.A., Francois, R., 2008. Particulate organic carbon fluxes to the ocean interior and factors controlling the biological pump: a synthesis of global sediment trap programs since 1983. Prog. Oceanogr. 76 (3), 217-285.

Hu, C., Lee, Z., Franz, B.A., 2012. Chlorophyll- $a$ algorithms for oligotrophic oceans: a novel approach based on three-band reflectance difference. J. Geophys. Res. 117, C01011. https://doi.org/10.1029/2011JC007395.

Izagirre, U., Ramos, R.R., Marigómez, I., 2008. Natural variability in size and membrane stability of lysosomes in mussel digestive cells: seasonal and tidal zonation. Mar. Ecol. Prog. Ser. 372, 105-117.

Kautsky, N., 1982. Quantitative studies on gonad cycle, fecundity, reproductive output and recruitment in a Baltic Mytilus edulis population. Mar. Biol. 68 (2), 143-160.

Kilpatrick, K.A., Podestá, G., Walsh, S., Williams, E., Halliwell, V., Szczodrak, M., Brown, O.B., Minnett, P.J., Evans, R., 2015. A decade of sea surface temperature from MODIS. Remote Sens. Environ. 165, 27-41.

Kim, Y., Ashton-Alcox, K.A., Powell, E.N., 2006. Histological Techniques for Marine Bivalve Molluscs: Update. Silver Spring, MD. NOAA Technical Memorandum NOS NCCOS 27 (76 pp).

Kopecka, J., Lehtonen, K.K., Baršienė, J., Broeg, K., Vuorinen, P.J., Gercken, J., Balk, L., Pempkowiak, J., 2006. Measurements of biomarker levels in flounder (Platichthys flesus) and blue mussel (Mytilus trossulus) from the Gulf of Gdańsk (southern Baltic). Mar. Pollut. Bull. 53, 406-421.

Kozlov, I., Dailidienè, I., Korosov, A., Klemas, V., Mingèlaitė, T., 2014. MODIS-based sea surface temperature of the Baltic Sea Curonian Lagoon. J. Mar. Syst. 129, 157-165 https://doi.org/10.1016/j.jmarsys.2012.05.011.

Lahdes, E.O., Farkas, T., Lehtonen, K.K., 2010. Phospholipid characteristics and neutral lipid fatty acid composition related to temperature and nutritional conditions in ecologically important amphipod species from the northern Baltic Sea. J. Exp. Mar. Biol. Ecol. 390, 125-133.

Larsson, J., Smolarz, K., Świeżak, J., Turower, M., Czerniawska, N., Grahn, M., 2018. Aquat. Toxicol. 198, 240-256

Lehtonen, K., 1989. The effects of oil and dispersant on the blue mussel (Mytilus edulis L.) of the quark region in the Gulf of Bothnia. Vesi- ja ympäristöhallinnon julkaisuja 33 (in Finnish).

Lehtonen, K.K., Kankaanpää, H., Leiniö, S., Sipiä, V.O., Pflugmacher, S., Sandberg-Kilpi, E., 2003. Accumulation of nodularin-like compounds from the cyanobacterium Nodularia spumigena and changes in acetylcholinesterase activity in the clam Macoma balthica during short-term laboratory exposure. Aquat. Toxicol. 64, 461-476.

Leiniö, S., Lehtonen, K.K., 2005. Seasonal variability in biomarkers in the bivalves Mytilus edulis and Macoma balthica from the northern Baltic Sea. Comparative Biochemistry and Phyisiology part C $140,408-421$.

Lowe, D.M., Moore, M.N., 1979. The cytology and occurrence of granulocytomas in mussels. Mar. Pollut. Bull. 10 (5), 137-141

Lowe, D.M., Moore, M.N., Clarke, K.R., 1981. Effects of oil on digestive cells in mussels: quantitative alterations in cellular and lysosomal structure. Aquat. Toxicol. 1 (3-4), 213-226.

Malagoli, D., Casarini, L., Sacchi, S., Ottaviani, E., 2007. Fish \& Shellfish Immunology 23 (1), 171-177.

Marigómez, I., Baybay-Villacorta, L., 2003. Pollutant-specific and general lysosomal responses in digestive cells of mussels exposed to model organic chemicals. Aquat. Toxicol. 64 (3), 235-257.

Marigómez, I., Izagirre, U., Lekube, X., 2005. Lysosomal enlargement in digestive cells of mussels exposed to cadmium, benzo[a]pyrene and their combination. Comparative biochemistry and physiology Part C: Toxicology \& Pharmacology 141 (2), 188-193.

Marigómez, I., Soto, M., Cancio, I., Orbea, A., Garmendia, L., Cajaraville, M.P., 2006. Cell and tissue biomarkers in mussel, and histopathology in hake and anchovy from Bay of Biscay after the prestige oil spill (Monitoring Campaign 2003). Mar. Pollut. Bull. 53 287-304.

Marigómez, I., Garmendia, L., Soto, M., Orbea, A., Izagirre, U., Cajaraville, M.P., 2013. Marine ecosystem health status assessment through integrative biomarker indices: a comparative study after the prestige-oil spill mussel watch. Ecotoxicology 22, 486-505.

Moore, M.N., 1976. Cytochemical demonstration of latency of lysosomal hydrolases in digestive cells of the common mussel, Mytilus edulis, and changes induced by thermal stress. Cell Tissue Res. 175 (3), 279-287.

Moukrim, A., Id Halla, M., Kaaya, A., Bouhaimi, A., Benomar, S., Mathieu, M., 2008. Pattern of reserve storage of the two mussel species Perna perna and Mytilus galloprovincialis living on Moroccan coasts: annual variation and effect of pollution. Iberus 26 (1) $17-28$.

Mújica, M., Izagirre, U., Marigómez, I., 2015a. Lysosomal responses to heat-shock of seasonal temperature extremes in Cd-exposed mussels. Aquat. Toxicol. 164, 99-107.

Mújica, M., Sokolova, I.M., Izagirre, U., Marigómez, I., 2015b. Season-dependent effects of elevated temperature on stress biomarkers, energy metabolism and gamete development in mussels. Mar. Environ. Res. 103, 1-10.

Nahrgang, J., Brooks, S.J., Evenset, A., Camus, L., Johnsson, M., Smith, T.J., Lukina, J., Frantzen, M., Giarratano, E., Renaud, P.E., 2013. Seasonal variation in biomarkers in blue mussel (Mytilus edulis), Icelandic scallop (Chlamys islandica) and Atlantic cod (Gadus morhua)-implications for environmental monitoring in the Barents Sea Aquat. Toxicol. 127, 21-35.

Nasci, C., Nesto, N., Monteduro, R.A., Da Ros, L., 2002. Field application of biochemical markers and physiological index in the mussel, Mytilus galloprovincialis: transplantation and biomonitoring studies in the lagoon of Venice (NE Italy). Mar. Environ. Res. 54 (3), 811-816.

Newell, R.I.E., 1989. Species Profiles: Life Histories and Environmental Requirements of Coastal Fish and Invertebrates (North and Mid-Atlantic) Blue Mussel. US Fish Wildlife Service for Biology and Reproduction 82 (11.102), US Army Corps of Engineers (TR EL-82-4). 
Ohkawa, H., Ohishi, N., Yagi, K., 1979. Assay for lipid peroxides in animal tissues by thiobarbituric acid reaction. Anal. Biochem. 95, 351-358.

Ortiz-Zarragoitia, M., Garmendia, L., Barbero, M.C., Serrano, T., Marigómez, I., Cajaraville M.P., 2011. Effects of the fuel oil spilled by the Prestige tanker on reproduction parameters of wild mussel populations. J. Environ. Monit. 13, 84-94.

Pearse, A.G.E., 1985. Histochemistry. Theoretical and Applied. Vol 2. Analytical Technology. Churchill Livingstone, London, p. 1055.

Potrykus, J., Albalat, A., Pempkowiak, J., Porte, C., 2003. Content and pattern of organic pollutants (PAHs, PCB's and DDT) in blue mussels (Mytilus trossulus) from the southern Baltic Sea. Oceanologia 45, 337-355.

R Core Team, 2018. R: A Language and Environment for Statistical Computing. R Foundation for Statistical Computing, Vienna, Austria https://www.R-project.org/.

Raateoja, M., Kuosa, H., Hällfors, S., 2011. Fate of excess phosphorus in the Baltic Sea: a real driving force for cyanobacterial blooms? J. Sea Res. 65, 315-321.

Raateoja, M., Hällfors, H., Kaitala, S., 2018. Vernal phytoplankton bloom in the Baltic Sea: intensity and relation to nutrient regime. J. Sea Res. 138, 24-33.

Rasmussen, L.P.D., 1986. Occurrence, prevalence and seasonality of neoplasia in the marine mussel Mytilus edulis from three sites in Denmark. Mar. Biol. 92, 59-64.

Regoli, F., 1998. Trace metals and antioxidant enzymes in gills and digestive gland of the Mediterranean mussel Mytilus galloprovincialis. Arch. Environ. Contam. Toxicol. 34 48-63.

Rementeria, A., Mikolaczyk, M., Lanceleur, L., Blanc, G., Soto, M., Schäfer, J., Zaldibar, B., 2016. Assessment of the effects of $\mathrm{Cu}$ and $\mathrm{Ag}$ in oysters Crassostrea gigas (Thunberg, 1793) using a battery of cell and tissue level biomarkers. Mar. Environ. Res. 122, 11-22.

Rodriguez-Iruretagoiena, A., Rementeria, A., Zaldibar, B., Fdez-Ortiz de Vallejuelo, S. Gredilla, A., Arana, A., de Diego, A., 2016. Mar. Pollut. Bull. 111 (1-2), 95-105 15.

Shaw, J.P., Large, A.T., Donkin, P., Evans, S.V., Staff, F.J., Livingstone, D.R., Chipman, J.K., Peters, L.D., 2004. Seasonal variation in cytochrome P450 immunopositive protein levels, lipid peroxidation and genetic toxicity in digestive gland of the mussel Mytilus edulis. Aquat. Toxicol. 67 (4), 325-336.

Shaw, J.P., Dondero, F., Moore, M.N., Negri, A., Dagnino, A., Readman, J.W., Lowe, D.R. Frickers, P.E., Beesley, A., Thain, J.E., Viarengo, A., 2011. Integration of biochemical, histochemical and toxicogenomic indices for the assessment of health status of mussels from the Tamar Estuary, U.K. Mar. Environ. Res. 72 (1-2), 13-24.

She, J., Høyer, J.L., Larsen, J., 2007. Assessment of sea surface temperature observational networks in the Baltic Sea and North Sea. J. Mar. Syst. 65, 314-335. https://doi.org/ 10.1016/j.jmarsys.2005.01.004.

Sheehan, D., Power, A., 1999. Effects of seasonality on xenobiotic and antioxidant defence mechanisms of bivalve molluscs. Comp. Biochem. Physiol. C: Pharmacol. Toxicol. Endocrinol. 123 (3), 193-199.
Smolarz, K., Hallmann, A., Zabrzańska, S., Pietrasik, A., 2017. Elevated gonadal atresia as biomarker of endocrine disruptors: field and experimental studies using Mytilus trossulus (L.) and 17 alpha ethinylestradiol (EE2). Mar. Pollut. Bull. 120 (1-2), 58-67.

Storhaug, E., Nahrgang, J., Bondo, K., Brooks, S.J., Petes, L., Bakhmet, I.N., Frantzen, M., 2018. Seasonal and spatial variations in biomarker baseline levels within Arctic populations of mussels (Mytilus spp.). STOTEN https://doi.org/10.1016/j. scitotenv.2018.11.397.

Stramski, D, Reynolds, R.A. Babin, M, Kaczmarek, S, Lewis, M.R, Röttgers, R, Sciandra, A Stramska, M., Twardowski, M.S., Franz, B.A., Claustre, H., 2008. Relationships between the surface concentration of particulate organic carbon and optical properties in the eastern South Pacific and eastern Atlantic oceans. Biogeosciences 5, 171-201.

Suárez Alonso, P., Álvarez González, C., Molist, P., San Juan, F., 2005. Particular aspects of gonadal cycle and seasonal distribution of gametogenic stages of Mytilus galloprovincialis cultured in the Estuary of Vigo. J. Shellfish Res. 24, 531-540.

Sunila, I., 1987. Histopathology of mussels (Mytilus edulis L.) from the Tvärminne area, the Gulf of Finland (Baltic Sea). Ann. Zool. Fenn. 24, 55-69.

Turja, R., Lehtonen, K.K., Meierjohann, A., Brozinski, J.M., Vahtera, E., Soirinsuo, A., Sokolov, A., Snoeijs, P., Budzinski, H., Devier, M.H., Peluhet, L., Pääkkönen, J.P., Viitasalo, M., Kronberg, L., 2015. The mussel caging approach in assessing biological effects of wastewater treatment plant discharges in the Gulf of Finland (Baltic Sea). Mar. Pollut. Bull. 97, 135-149.

UNEP/RAMOGE, 1999. Manual of the Methods Recommended for the MED POL Biomonitoring Programme. vol. 1999. UNEP, Athens, Greece.

Viarengo, A., Canesi, L., Pertica, M., Livingstone, D.R., 1991. Seasonal variations in the antioxidant defence systems and lipid peroxidation of the digestive gland of mussels. Comp. Biochem. Physiol. 100C, 187-190.

Vidal, M.L., Bassères, A., Narbonne, J.F., 2002. Seasonal variations of pollution biomarkers in two populations of Corbicula fluminea (Müller). Comp. Biochem. Physiol. 131C, 133-151.

Wasmund, N., Göbel, J., Bodungen, B.v., 2008. 100-years-changes in the phytoplankton community of Kiel Bight (Baltic Sea). J. Mar. Syst. 73 (3-4), 300-322.

Weibel, E.R., 1979. Stereological Methods: Vol 1. Practical Methods for Biological Morphometry. Academic Press, London.

Zorita, I., Ortiz-Zarragoitia, M., Soto, M., Cajaraville, M.P., 2006. Biomarkers in mussels from a copper site gradient (Visnes, Norway): an integrated biochemical, histochemical and histological study. Aquat. Toxicol. 78, 109-116. 